\title{
Risk Factors and Control Measures for Bacterial Contamination in the Bovine Meat Chain: A Review on Salmonella and Pathogenic E.coli
}

\author{
Eugène Niyonzima ${ }^{1,2}$, Martin Patrick Ongol $^{2}$, Anastase Kimonyo ${ }^{2}$, Marianne Sindic $^{1}$ \\ ${ }^{1}$ University of Liège - Gembloux Agro Bio - Tech. Laboratory of Agro-food Quality and Safety. Passage des \\ Déportés 2, 5030 Gembloux, Belgium \\ ${ }^{2}$ University of Rwanda - College of Agriculture, Animal Sciences and Veterinary Medicine, School of Food \\ Science and Technology. PO Box 3900 Avenue de l'Armée, Kigali, Rwanda \\ Correspondence: Eugène Niyonzima, University of Liège - Gembloux Agro Bio - Tech. Laboratory of \\ Agro-food Quality and Safety. Passage des Déportés 2, 5030 Gembloux, Belgium. Tel: 32-465-434-099. E-mail: \\ eugeneniyo@yahoo.fr
}

Received: May 5, 2015 Accepted: July 30, 2015 Online Published: September 9, 2015

doi:10.5539/jfr.v4n5p98 URL: http://dx.doi.org/10.5539/jfr.v4n5p98

\begin{abstract}
Salmonella and pathogenic Escherichia coli are known to be the major bacterial agents responsible for human foodborne infections attributable to meat. A review of the specialized literature was carried out to identify the risk factors for bovine meat contamination by these pathogens from the cattle farm to meat consumption. Animal stress during transport to the slaughterhouse and the duration of the lairage period were identified as the key factors influencing the faecal excretion of Salmonella and pathogenic E. coli as well as cattle contamination prior to slaughter. At the abattoir level, hides and visceral contents appear to be the main sources of pathogenic bacteria that contaminate carcasses along the meat production chain. Finally, temperature abuses during distribution and meat contamination by infected handlers were found to be important contributors to the post-slaughter contamination of bovine meat. The findings of this study indicate that efficient management of human food borne infections attributable to bovine meat requires an integrated application of control measures involving all actors along the meat chain, namely slaughterhouses, meat processing plants, distributors and consumers.
\end{abstract}

Keywords: bovine meat, Salmonella, pathogenic E. coli, safety, risk factors

\section{Introduction}

Meat is consumed in different parts of the world as a source of animal proteins (Food and Agriculture Organization, 2013) and its chemical composition is favourable for the proliferation of a wide range of microbial populations which makes raw meat to be one of the vehicles of foodborne infections in humans (Doulgeraki, Ercolini, Villani, \& Nychas, 2012; Scallan et al., 2011). The actual number of foodborne infections attributable to meat is difficult to assess accurately, principally because only a small proportion of illness cases is officially reported especially in developing countries. On the other hand, even within the reported cases, only a limited number allow identification of the food vehicle. Data from outbreaks constitute an interesting source of information to associate foodborne illness cases to their respective food vehicles and causal agents (Scallan et al., 2011). Greig and Ravel (2009), by using outbreak data published internationally from 1996 to 2005, noted that $12.7 \%$ of reported foodborne outbreaks were attributable to bovine meat while 10.5 and $4.6 \%$ were associated with chicken and pork, respectively. According to the same authors, Salmonella and pathogenic Escherichia coli, respectively, were identified as the causal agents in 32.9 and $34.6 \%$ of foodborne outbreaks of bacterial origin attributable to beef.

Several studies have addressed the sources and potential control measures of bovine meat contamination by Salmonella and pathogenic $E$. coli at different stages of the meat chain i.e. primary production (Barkocy-Gallagher et al., 2003; Millemann, 2008), animal transportation to the slaughterhouse (Arthur et al., 2007; Barham et al., 2002) ; slaughtering operations (Antic et al., 2010); further processing (Carney et al., 2006; Scanga et al., 2000), distribution (Haileselassie, Taddele, Adhana, Kalayou, \& Tadesse, 2013); cooking (Juneja, Eblen, \& Ransom, 2001); however literature on bovine meat contamination and possible control measures considering the entire meat chain is still limited, probably because of the length and the complexity of the chain. 
The contamination of meat by microbial pathogens can occur at any stage of the meat chain (Duffy, Cummins, Nally, O' Brien, \& Butler, 2006; Rhoades, Duffy, \& Koutsoumanis, 2009). Furthermore, the prevention or mastery of meat contaminations can be carried out at a stage of the chain different from the stages at which the contamination has occurred (Chen et al., 2012). Therefore, the food chain approach constitutes an efficient method to control bacterial contaminations of meat at consumption. The objective of this study was to review the existing knowledge on sources and risk factors for bovine meat bacterial contamination and provide an up to date view on control measures of the same by using a meat chain approach. The focus was put on Salmonella and pathogenic E. coli, as they are reported to be the leading causes of foodborne bacterial infections attributable to bovine meat (Greig \& Ravel, 2009).

The literature search was undertaken first by reviewing literature in databases of peer-reviewed scientific publications, namely Scopus, PubMed and Google Scholar, using the following key words: cattle, bovine, beef, meat, safety, abattoir, slaughter, slaughterhouse, salmonella, salmonellosis, Escherichia coli, microbial (bacterial) contamination, hygiene, risk factors and distribution. Only articles in English or French were retained. On the other hand, books and other official publications dealing with the subject were consulted.

In this paper, an overview of the prevalences of Salmonella and pathogenic E. coli in bovine meat was carried out before tackling their risk factors along the bovine meat chain and discussing their respective control measures.

\section{Salmonella and Pathogenic E. coli in Bovine Meat}

Contaminated bovine meat is considered to be one of the sources of foodborne Salmonella and pathogenic E. coli infections in humans. The reported prevalence of Salmonella and pathogenic E. coli in bovine meat and products thereof varies from one product to another, but wide variability is also observed amongst different countries (Tables 1 and 2). The prevalences are globally lower in bovine carcasses at the slaughterhouse level and higher in meat cuts and minced beef at retail (EFSA and ECDC, 2013b; Stevens et al., 2006). This could be associated with bacterial contamination of meat that can occur during the transport of bovine carcasses from the slaughterhouse to the meat processing units, during cutting and mincing operations within meat processing plants and/or during the marketing of bovine meat in retail outlets. Niyonzima et al., (2013) reported a $2.2 \log$ cfu increase in E. coli load between the slaughtering and marketing of beef at a commercial abattoir in Kigali city (Rwanda). Similarly, an increase in the prevalence and concentration of Salmonella and E. coli during the cutting and mincing of bovine meat is generally reported in meat processing plants (Hassanein, Fathi, Ali, \& El-malek, 2011; Rhoades et al., 2009; Scanga et al., 2000). The variations in Salmonella and pathogenic E. coli prevalence amongst different countries could be attributed to a number of factors (including the farming systems and practices, slaughtering practices and post slaughter handling of meat as well as the general hygiene at different stages of the meat chain); which differ from one country to another. Higher prevalences are principally observed in developing countries, where poor hygienic conditions during slaughtering and meat handling are generally reported (Gashe \& Mpuchane, 2000; Hassanein et al., 2011; Magwira, Gashe, \& Collison, 2005; Stevens et al., 2006), whereas lower prevalence are mostly observed in developed countries where good hygienic practices are reported to be strictly followed and monitored along the meat chain (EFSA and ECDC, 2013; Vipham et al., 2012; Bosilevac et al., 2009).

The reported prevalence in different countries would be, however, not comparable because of differences in the sampling strategy and the analytical methods used. In some studies the number of analyzed samples amounted to thousands (Bosilevac et al., 2009; EFSA and ECDC, 2013b), whereas in others only a very limited number of samples was analysed (Gashe \& Mpuchane, 2000; Temellï, Eyİgör, \& Anar, 2012). Differences were also observed in sampling methodology, where the surface swabbed on bovine carcasses to detect pathogens or the weight of the meat samples analysed varied between different studies. In the studies conducted in European Union countries for example, the surface area covered by a carcass swab was reported to vary from 100 to 600 $\mathrm{cm}^{2}$, while the weight of the meat sample analysed varied from 1 to $25 \mathrm{~g}$ (EFSA and ECDC, 2013b, 2014). Additionally, the analytical methods used to detect Salmonella and pathogenic E. coli in meat and meat products differed from one study to another. For Salmonella, a culturing method including a pre-enrichment phase in buffered peptone water, a selective enrichment and isolation followed by biochemical confirmation of isolates was the predominant method used (Bosilevac et al., 2009; Tafida et al., 2013). However, in other studies other detection methods such as PCR were used alone or in combination with a culturing method (Hassanein et al., 2011; Vipham et al., 2012). The same trend was observed in the methodology used to detect verotoxinogenic $E$. coli in meat and meat products (TemellI et al., 2012). The prevalence of Salmonella or pathogenic E. coli in faeces, on hides or on bovine carcasses was reported to be higher when a PCR-based method was used than when the pathogen was detected by conventional culturing methods (Barkocy-Gallagher et al., 2003; Mainil \& 
Daube, 2005). This would be due to the fact that PCR methods consider the bacterial DNA and take into account all the bacterial cells, whether living or dead; whereas the culture method only consider living bacterial cells (Johansson et al., 2000).

Even if differences in the sampling strategy and analytical methods used in different studies do not allow an accurate comparison of the prevalence of pathogenic E. coli and Salmonella in meat amongst different countries, it appears that these two pathogens are detectable worldwide in significant proportions in meat in general, and particularly in bovine meat. According to the EFSA and ECDC report (2014) on zoonoses, data collected in 2012 from nine European Union member states showed prevalences of 1.3 and $0.1 \%$, respectively, for verocytotoxigenic E. coli (VTEC) and VTEC O157 in fresh bovine meat. The prevalence of VTEC in meat from animal species other than bovines in the EU was not estimated, probably because of the non-representativeness of the data available. However, the prevalence of VTEC in different Member States in 2011 was reported to be higher in bovine meat compared to meat from other animal species.This could be probably due to the fact that the enteric carriage of pathogenic E. coli is mostly observed in cattle than in other animal species (Mainil \& Daube, 2005). In Ireland, VTEC was detected in 1\% of 291 bovine carcass samples, while no positive finding was reported from 134 sheep carcass samples (EFSA and ECDC, 2013b).

Table 1. The prevalence of Salmonella in fresh bovine meat

\begin{tabular}{|c|c|c|c|c|}
\hline Product & $\begin{array}{l}\% \text { of positive } \\
\text { samples }\end{array}$ & $\begin{array}{l}\text { Number of tested } \\
\text { samples }\end{array}$ & Country & References \\
\hline \multirow[t]{4}{*}{ Beef carcasses } & 42.8 & 236 & Senegal & (Stevens et al., 2006) \\
\hline & 0.2 & 1275 & Australia & (Phillips et al., 2001) \\
\hline & 6 & 250 & Mexico & (Narvaez-Bravo et al., 2013) \\
\hline & 0 & 53 & Poland & (EFSA and ECDC, 2014) \\
\hline \multirow[t]{9}{*}{ Butcher shop beef } & 20 & 25 & Egypt & (Hassanein et al., 2011) \\
\hline & 9.9 & 354 & Botswana & (Gashe \& Mpuchane, 2000) \\
\hline & 2.4 & 370 & Nigeria & (Tafida et al., 2013) \\
\hline & 1.02 & 2885 & USA & (Vipham et al., 2012) \\
\hline & 0.8 & 274 & France & (EFSA and ECDC, 2014) \\
\hline & 0.3 & 747 & Germany & (EFSA and ECDC, 2014) \\
\hline & 1.1 & 117 & Hungry & (EFSA and ECDC, 2014) \\
\hline & 0 & 26 & Italy & (EFSA and ECDC, 2014) \\
\hline & 0.9 & 649 & Netherland & (EFSA and ECDC, 2014) \\
\hline \multirow[t]{3}{*}{ Ground beef } & 20 & 25 & Botswana & (Gashe \& Mpuchane, 2000) \\
\hline & 11 & 88 & Mexico & (Heredia et al., 2001) \\
\hline & 4.2 & 4136 & USA & (Bosilevac et al., 2009) \\
\hline
\end{tabular}

A comparable observation was reported in the Czech Republic, where $0.3 \%$ of 1159 bovine carcasses were reported to be positive for VTEC while not a single positive sample was found in 1395 pig carcasses (EFSA and ECDC, 2013b). At the retail level, the Netherlands reported $0.3 \%$ of 702 bovine meat samples were positive for VTEC while no positive sample was found from 86 sheep meat samples (EFSA and ECDC, 2013b). In contrast, a higher prevalence of VTEC was reported in Spain, where $2.9 \%$ of 34 poultry samples were found to be positive for VTEC against a prevalence of $0.0 \%(n=45)$ in bovine meat (EFSA and ECDC, 2013b). 
Table 2. The prevalence of pathogenic E. coli in fresh bovine meat

\begin{tabular}{lllll}
\hline Product & $\begin{array}{l}\text { \% of positive } \\
\text { samples }\end{array}$ & $\begin{array}{l}\text { Number of tested } \\
\text { samples }\end{array}$ & Country & References \\
\hline Beef carcasses & 0.4 & 250 & Mexico & (Narvaez-Bravo et al., 2013) \\
& 0.9 & 453 & Belgium & (EFSA and ECDC, 2014) \\
& 1.3 & 622 & Czech Rep. & (EFSA and ECDC, 2014) \\
& 5.7 & 315 & Germany & (EFSA and ECDC, 2014) \\
Butcher shop meat & 0 & 203 & Romania & (EFSA and ECDC, 2014) \\
& 10 & 20 & Turkey & (Temelli et al., 2012) \\
& 11.1 & 27 & Egypt & (Mohammed et al., 2014) \\
& 5.22 & 134 & Botswana & (Magwira et al., 2005) \\
Ground beef & 1.8 & 492 & Germany & (EFSA and ECDC, 2013b) \\
& 0 & 45 & Spain & (EFSA and ECDC, 2013b) \\
& 3.2 & 555 & Netherland & (EFSA and ECDC, 2014) \\
& 3.76 & 133 & Botswana & (Magwira et al., 2005) \\
& 3.85 & 52 & Turkey & (Temelli et al., 2012) \\
& 16.7 & 30 & Egypt & (Mohammed et al., 2014) \\
& 3.8 & 479 & Germany & (EFSA and ECDC, 2013b) \\
\hline
\end{tabular}

The prevalence of Salmonella in bovine meat has been found to be low compared to meat from other animal species. In the European Union, during 2012, the prevalence of Salmonella in bovine meat and products thereof was reported to be $0.2 \%$ whereas in pig and broiler meat it was estimated to be 0.7 and $4.1 \%$, respectively (EFSA and ECDC, 2014). The highest Salmonella prevalence observed in poultry meat could be attributed to the colonization of the reproductive tract of infected subjects by the pathogen that may increase the probability of Salmonella dissemination on carcasses under preparation through cross contamination (Gast, Guraya, Guard-Bouldin, Holt, \& Moore, 2007). Although the prevalence of Salmonella in bovine meat seems to be relatively low, contaminated bovine meat remains a significant risk for Salmonella infection in humans, particularly for people consuming more beef than meat from other animal species. Additionally, the high protein and fat content of foods such as meat was reported to protect the bacterium against the gastric acidity (Birk et al., 2012; Blaser \& Newman, 1982; Kothary \& Babu, 2001). This suggests that the consumption of contaminated meat, even with a limited number of pathogens, would present a significant risk of infection and/or intestinal colonization in humans.

As for other bacterial pathogens, the minimum number of Salmonella capable of causing illness, is difficult to determine as it depends on a number of factors including (but not limited to) the food matrix, the host susceptibility and the virulence factors of the pathogen (McEntire, Acheson, Siemens, Eilert, \& Robach, 2014). However, recent studies using outbreak data indicate that doses as low as 36 colony forming units can cause illness in humans (Teunis et al., 2010). This infective dose would be qualified as "low "comparatively to foodborne pathogens such as Vibrio cholerae that require doses as high as $10^{4}-10^{8}$ cells to cause infection in humans (Kothary \& Babu, 2001). The infective dose for pathogenic $E$ coli is also known to be "low". Coia (1998) reported contamination levels as low as 2 organisms per 25 grams in food and environmental samples incriminated in VTEC O157 outbreaks. Because of the low infective dose, the contamination limit for these pathogens has been fixed to the absence in $25 \mathrm{~g}$ of meat preparations intended to be eaten raw (European Commission, 2005).

It is assumed that the level of microbial contamination of meat at the end consumer stage is function of contaminations acquired during different stages of meat preparation. Therefore, reducing the prevalence of foodborne infections such as Salmonella and verotoxinogenic E. coli attributable to bovine meat in humans requires integrated control measures involving all actors in the bovine meat chain from primary production to the final consumer. 


\section{Bacterial Contamination of Bovine Meat along the Production Chain}

\subsection{Preslaughter Contamination of Live Cattle}

Salmonella infection is commonly reported in different animal species. Considering their adaptation to hosts, Salmonella serotypes are grouped in three categories: namely serotypes only pathogenic for humans like $S$. Typhi and $S$. Paratyphi; serotypes adapted to animal species such as $S$. Gallinarum, $S$. Dublin, $S$. Abortusequi, $S$. Abortusovis and $S$. Choleraesuis which are pathogenic for poultry, cattle, horses, sheep, and pigs respectively; and finally ubiquitous serovars like $S$. Typhimurium and $S$. Enteritidis adapted to humans and other animal species (Jay et al., 2005). In cattle, Salmonella infection can be clinically manifested by a wide range of symptoms including diarrhoea and possible dysentery, joint infections, pneumonia as well as abortions (Millemann, 2008). However, bovines may also carry Salmonella in their gastro-intestinal tract without any clinical symptom of the disease. In the latter case bovines are called asymptomatic carriers. In both infected and asymptomatic carriers, Salmonella can be excreted through the faeces for a relatively long period. Gopinath et al. (2012) reported that the faecal shedding of Salmonella in cattle may last up to 400 days.

As with Salmonella, asymptomatic carriage and faecal shedding of pathogenic E. coli are common in bovines of all ages; but clinical manifestations of the disease are mainly observed in young calves with 2 weeks to 2 months of age with diarrhoea as the main symptom (Alexa, Konstantinova, \& Sramkova-Zajakova, 2011; Millemann, 2008). The duration of faecal shedding in cattle can last up to 19 weeks (Khaitsa et al., 2003). On a clinical basis, pathogenic $E$. coli strains are grouped in 3 classes namely those rarely associated to diseases either in animals or in humans (i.e VTEC-2), strains associated to disease in both animals and humans (i.e EHEC-2) and finally strains such as EHEC-1 and VTEC-1 reported to be highly infectious for humans but rarely in animals (Mainil \& Daube, 2005).

The faecal shedding of Salmonella and pathogenic E. coli constitutes an important factor of cattle contamination. In fact, pathogens excreted in the faeces may contaminate the environment through which other cattle can acquire contamination and carry the bacteria in their digestive tract and/or on their hides (Rhoades et al., 2009). The contamination of live cattle destined for slaughter may occur at the farm level, during the transportation of bovines to the slaughterhouse or during the lairage period in the abattoir.

At the farm level, contaminated feed and water have been reported to be the main sources of Salmonella and pathogenic E. coli infections in cattle (Millemann, 2008). However, dissemination of the infection within the herd is mainly attributable to faecal excretion of the pathogens. The prevalence of pathogenic E. coli and Salmonella is generally reported to be higher on cattle hides than in the faeces. This is due to the fact that a single animal shedding the pathogen in its faeces may contaminate the hides of many other animals in the herd, either directly or via the ground and lairage fixtures (Small et al., 2002). In a study conducted on 200 steers and heifers in a large feed yard, Barham et al. (2002) reported an E. coli $\mathrm{O} 157$ prevalence of $18 \%$ on hides while its prevalence in faeces was as low as 9.5\%. A similar relationship was reported by Barkocy-Gallagher et al. (2003), who detected $E$. coli $\mathrm{O} 157: \mathrm{H} 7$ on $60.6 \%$ of cattle presented for slaughter, while the faecal prevalence was $5.9 \%$. As with VTEC, Salmonella prevalence was reported to be higher on cattle hides than in faeces. Barkocy-Gallagher et al. (2003) reported a Salmonella prevalence of $71 \%$ on the hides of feedlot cattle while a prevalence of only $4.3 \%$ was recorded from faecal samples of the same group.

The control of pathogenic E. coli and Salmonella infections on cattle farms includes the treatment of all carriers and infected subjects but also limiting the spread and severity of the disease. When the infection is identified early in the herd and few animals are affected, their isolation is an important measure to consider. Furthermore, faecal dejections from infected animals should be managed in a manner to avoid contamination of feed, water or livestock equipments. Antibiotic therapy, especially in subjects affected by salmonellosis, should be used cautiously as the emergence of Salmonella strains resistant to antibiotics commonly used in veterinary medicine is reported to be increasing (EFSA and ECDC, 2013a; Stevens et al., 2006). The treatment of E. coli and Salmonella infections in cattle herds has been thoroughly reviewed by Millemann (2008) and is not further developed in this paper.

The faecal shedding of pathogens from asymptomatic carriers constitutes a serious obstacle on the control of Salmonella and pathogenic E. coli infections in cattle; as shedders are not clinically identifiable and in most of times, not subjected to treatment. Traditionally, asymptomatic carriers can be detected through the culture of multiple faecal samples collected from suspected shedders during a relatively long period (Gopinath et al., 2012; Guy, Tremblay, Beausoleil, Harel, \& Champagne, 2014). However, this approach presents a disadvantage of being logistically difficult to conduct and inefficient especially in carriers where the faecal shedding of Salmonella or pathogenic E. coli is intermittent (Edrington et al., 2004; Fitzgerald et al., 2003). As 
an alternative to the cultural methods, serological methods that consist in the detection of antibodies specifically directed against some antigens expressed by the pathogen exist. An example is the measurement of immunoglobulins directed against O-antigens from Salmonella Dublin in the blood that was reported to be used as an indicator of Salmonella infection in cattle (Robertsson, 1984). However, further studies indicate that serological tests are indicative on the current and/or previous infection status of the subjects but not on their shedding status (Olopoenia \& King, 2000). Therefore, considering the importance of the detection of shedders in the control of Salmonella and pathogenic E. coli infections in cattle farms and the weaknesses of the existing methods, it is recommended to develop more sensitive methods to detect shedding animals in the herd. Meanwhile, one should consider an approach consisting of serological screening followed up by a faecal culture of all seropositive animals to detect active carriers (Nielsen, 2013).

Animal stress is known to induce high levels of secretion of Salmonella and pathogenic E. coli in cattle faeces and increase the probability of contaminating healthy animals (Gopinath et al., 2012; Mainil \& Daube, 2005). During their transport to the slaughterhouse cattle may be subjected to a number of stresses, including high stocking densities, long transport duration, abnormal temperatures, noise pollution and changes in the general environment that can significantly increase the number of shedders. Cattle can also be infected by pathogenic microorganisms from a contaminated truck that has not been properly cleaned and disinfected or by direct contact with infected animals embedded in the same truck. Similarly, contaminated transport trucks can be a source of infection for slaughterhouses and farms initially free of Salmonella or pathogenic E. coli. At the slaughterhouse level, cattle are kept in lairage before killing them. In Europe and the United States, cattle are generally slaughtered on the day of their arrival to the abattoir, while in other countries they are usually slaughtered the day after. In the latter case, the period of lairage allows animals to rest, rehydrate and recover from the stress of transport (Ferguson \& Warner, 2008). During the period of lairage, cattle can be subjected to these same stress factors that increase the risk of contamination. On the other hand, in most cases the lairage is only cleaned at the end of the day and is therefore a potential source of contamination for cattle that can acquire an infection from contaminated animals or a soiled environment (Beach, Murano, \& Acuff, 2002). Different authors have reported significant increases in pathogen prevalences on cattle hides during their transport and in the lairage period in the slaughterhouse. In a study conducted on 286 cattle, Arthur et al. (2007) reported that the prevalence of $E$. coli O157:H7 on hides increased from 50.3 to $94.4 \%$ between the time the cattle were loaded onto tractor-trailers at the feedlot and the time their hides were removed in the slaughterhouse. Similarly, Barham et al. (2002) reported an increase in Salmonella prevalence on cattle hides (from 6 to 89\%) during the transport and lairage of 200 cattle, whereas the prevalence of Salmonella in the faeces of the same group increased from 18 to $46 \%$.

A number of measures could contribute significantly to reducing the risk of bacterial contamination of cattle destined for slaughter in the preslaughter environment. At the farm level, cattle destined for slaughter should be clean and dry with no visible dirt on their hides (Antic et al., 2010). Any practice that can generate animal stress during transport, such as mixing cattle from different farms and over loading trucks should be avoided (Small \& Buncic, 2009). Likewise, trucks should be cleaned and disinfected after each transport of cattle (Swanson \& Morrow-Tesch, 2001). At the abattoir, the lairage period should be kept to a strict minimum. Heavily contaminated animals must be separated from the others and the lairage pens must be cleaned and disinfected at the end of each slaughtering day and monitored by visual and bacteriological control (Wong et al., 2002).

\subsection{Contamination During the Slaughtering Process}

In the abattoir, the cattle slaughtering process includes successive steps, namely: stunning, sticking, skinning, evisceration, carcass splitting, refrigeration and eventually cutting and deboning (Figure 1) that can contribute significantly to the overall microbial load of bovine carcasses and meat cuts. In this section, sources, risk factors and control measures for meat contamination by Salmonella and pathogenic E. coli throughout the cattle slaughtering process are reviewed and discussed.

\subsubsection{Cattle Stunning}

Stunning is an operation that aims to render animals destined for slaughter unconscious prior to sticking and bleeding. It allows suffering by the animals to be minimised during the slaughtering process, especially the sticking. Beside animal welfare considerations, stunning also makes the throat-slitting less hazardous for the operator (Food and Agriculture Organization, 2006). Although chemical and electrical stunning methods are allowed in domestic ungulates, mechanical stunning is the most commonly used stunning method in cattle (Gregory et al., 2000). The devices used for mechanical stunning can be of a penetrating or non-penetrating type. A number of studies have been conducted to address possible microbial contamination of meat during the stunning process. In one experimental study, Buncic et al. (2002) demonstrated that the use of a penetrating 
captive bolt (PCB) in sheep presents a risk of microbial contamination for stunned animals through the stun wound. Marked organisms (E. coli K12 or Ps. fluorescens) were inoculated into the brains of sheep through the stun wound immediately after stunning by a cartridge-operated, penetrative captive bolt pistol. The marked organisms were found in blood, liver, lungs, spleen and lymph nodes and on the surface of inoculated animals. When the same pistol was then used to stun subsequent healthy sheep, marked organisms were found in the blood of $30 \%$ to $40 \%$ of the animal carcasses. Similar findings were reported by Daly et al. (2002) after inoculation of a marker strain of Ps. fluorescens into the central nervous system of cattle. Prendergast et al. reported dispersion of central nervous system tissues when a PCB was used for animal stunning.

Although the contamination of bovine carcasses by microorganisms introduced into the central nervous system during the stunning process by penetrating devices has been demonstrated experimentally, further studies are needed to assess the risk of such contaminations under commercial conditions. During the mentioned studies (Buncic et al., 2002; Daly et al., 2002), the levels of bacteria inoculated experimentally into the brain were relatively higher comparatively to the levels of bacteria commonly reported in slaughterhouses; suggesting that the risk of transmitting pathogens through the stun wound would be much lower under commercial conditions. However, as it known that Salmonella and pathogenic E. coli require low infective doses (Blaser \& Newman, 1982; Coia, 1998) the risk should be considered as significant. Beside the possible contamination of cattle via the contaminated stunning gun, different authors reported regular cross contamination of hides in the stun box between stunned animals consecutively fallen in the same box via contaminated surfaces (Small \& Buncic, 2009; Small et al., 2002) highlighting the need of a proper sanitation of the stun box.

As a control measure for food safety issues associated with the use of penetrating stunning devices in cattle, alternate stunning methods should be considered. The use of non-penetrating guns appears to be a good alternative. Nevertheless, potential problems associated with this type of gun, such as the frequent recovery before sticking, need to be resolved (EFSA, 2004). The use of electrical stunning seems to be another safer option (Anil et al., 2001). This method is used in different countries, namely New Zealand, Australia and the United Kingdom (Wotton, Gregory, Whittington, \& Parkman, 2000); however, its high cost and some doubts about animal welfare associated with the ineffective use of this method need to be addressed (Heim, Löpfe, Mumford, \& Speedy, 2007). Furthermore, the possibility of cleaning and disinfecting the stun box after stunning each animal should be considered to avoid cross contamination of hides from faecally soiled surfaces during the stunning process.

\subsubsection{Cattle Sticking}

Sticking is an operation that consists of severing the major blood vessels of the animal in order to extract the maximum amount of circulating blood during bleeding. Two sticking methods are generally used in cattle: thoracic and cervical sticking. Thoracic sticking includes a section of major blood vessels from the heart and allows rapid and complete bleeding, whereas during cervical sticking only vessels in the neck (carotid arteries and jugular veins) are cut and bleeding out is slower (Food and Agriculture Organization, 2006). The stick wound constitutes a channel that can allow the introduction of microbial contaminants into the carcass. The main source of contamination is the sticking knife, which can contaminate carcasses by direct transfer of bacteria from the transpierced skin but also by cross contamination if the knife is not sterilized between successive sticking operations.

In an experimental study (Mackey \& Derrick, 1979), it was demonstrated that microbial contamination of bovine carcasses can occur during sticking. Marked strains of E. coli, Cl. perfringens and Bacillus thuringiensis were placed on a sticking knife before use. After the sticking operations, marked organisms were isolated from the internal organs, namely the heart, lung, spleen, liver and kidneys and from muscles. However, even if the potential for meat contamination from the sticking knife has been shown under laboratory conditions, the risk of such transfers, especially for pathogens like Salmonella and pathogenic E. coli, under commercial conditions seems to be quite low. Mackey and Derrick (1979) reported that in order to induce contamination of the deep tissues of a carcass a large inoculum of $10^{10}$ to $10^{12}$ bacteria was required, whereas the actual level of contamination generally encountered in slaughterhouses is many orders of magnitude less. In a study conducted on bovine hides at a beef slaughter plant in Ireland, hide contamination by E. coli $\mathrm{O} 157$ was reported to be as low as 100 cfu per $100 \mathrm{~cm}^{2}$ or less in $90.8 \%$ of 109 cattle(O'Brien et al., 2005). Comparable findings were reported in the USA, where $62.7 \%$ of 124 cattle were found to carry fewer than $100 \mathrm{cfu} / 100 \mathrm{~cm}^{2}$ of $E$. coli $\mathrm{O} 157$ (Rhoades et al., 2009). The concentration of Salmonella on cattle hides is also known to be relatively low. In a study conducted on 100 cattle at slaughter, Fegan et al. (2005) reported a prevalence of $68 \%$ with the highest concentration being 4.8 MPN per $\mathrm{cm}^{2}$. Nevertheless, contaminated knives remain an important source of localised microbial contamination of the sticking wound (Rheault et al., 1999). Additionally, the sticking wound 
can be contaminated by microorganisms from the environment, especially when exsanguination is performed on animals lying on the ground.

In order to avoid/prevent microbial contamination of bovine carcasses through the sticking wound, cattle should be bled out in a suspended position to prevent contamination from the slaughtering environment (Food and Agriculture Organization, 2006); two separate knives should be used for sticking (one for the skin and another for muscles) and they should be decontaminated in hot water at $82^{\circ} \mathrm{C}$ or by another method with equivalent effect after being used (Eustace et al., 2007); and finally, the sticking site should be trimmed if any microbial contamination is suspected (Rheault et al., 1999).

\subsubsection{Hide Decontamination Treatments}

Cattle hides constitute one of the main sources of carcass contamination by bacterial pathogens such as Salmonella and pathogenic E. coli, whereas the contamination of hides is generally acquired from faeces of colonised animals or indirectly from the soiled environment (Arthur et al., 2010). The contamination of carcasses from soiled hides occurs during the skinning process. A number of intervention strategies to reduce the bacterial load on cattle hides and consequently reduce the risk of carcass contamination during skinning operations, have been addressed by various authors. These include physical, chemical and biological treatments applied alone or in combination. In this section major hide decontamination treatments are reviewed and their effect on reducing the bacteriological load on cattle hides is discussed.

The reported physical decontamination treatments include hide washing with cold or hot water, steam sprayings and cattle dehairing. Washing cattle hides with water has been found to remove dirt from the hides but seemed to have a minimal effect on the bacterial load of treated hides. The study by Mies et al. (2004) showed that washing cattle with cold water for 2 minutes did not permit significant reductions in aerobic bacteria, coliforms and $E$. coli on the hides. However, raising the water temperature from 15 to $60{ }^{\circ} \mathrm{C}$ reduced the load of aerobic bacteria by 0.5 logarithmic units (Bosilevac et al., 2005).

The effect of steam sprayings in decontaminating cattle hides was studied under laboratory conditions by McEvoy et al. (2003). These authors, by treating cattle hide pieces with steam at subatmospheric pressure during 1 to 20 seconds, reported reductions in total viable bacteria on treated hides of 2.9 to 3.9 logarithmic units after a treatment at $80^{\circ} \mathrm{C}$, while similar treatments at $75^{\circ} \mathrm{C}$ reduced total viable bacteria counts by only 1.9 to $2.6 \log$ units. In another study, reductions of inoculated E. coli $\mathrm{O} 157$ by 4.2 to $6.0 \mathrm{log}$ units were reported after spaying cattle hides by steam at $80^{\circ} \mathrm{C}$ during 10 to 20 seconds (McEvoy, Doherty, Sheridan, Blair, \& McDowell, 2001).

Dehairing cattle can be carried out by clipping the hide or using chemicals. The study by Small et al.(2005) showed that dehairing cattle hides with a clipper does not reduce the aerobic bacterial load on the hides, probably because of dust generation and subsequent dispersal of the bacteria. However, treating previously clipped hides with other physical or chemical hide decontamination methods was found to afford bacterial load reductions significantly higher than these obtained on unclipped hides (Baird et al., 2006). The use of chemical dehairing has been studied by Castillo et al. (1998). These authors, using a solution of sodium sulphide, water rinses, and hydrogen peroxide under laboratory conditions, achieved significant reductions in E. coli O157:H7 and $S$. Typhimurium previously inoculated on bovine hides (more than 4 logarithmic units). However, in a study conducted on 240 cattle in a commercial beef processing plant, Nou et al. (2003), using a similar method on cattle immediately after stunning, reported a reduction in E. coli $\mathrm{O} 157$ prevalence on the treated cattle hides from 88 to $67 \%$ without any significant reduction in aerobic bacteria or Enterobacteriacea populations.

A wide range of chemical antimicrobials have reportedly been used in hide decontamination treatments. These include organic acids (Mies et al., 2004), commercial detergents and disinfectants (Baird et al., 2006; Small et al., 2005), ozonated and electrolysed water (Bosilevac et al., 2005), and combinations of different chemicals (Carlson et al., 2008). However, their efficacy in reducing the bacterial load on cattle hides has been found to be dependent on a number of experimental factors such as the mode of application, the product concentration and temperature, the duration of exposure and the target microbial species. Limited studies have addressed the effect of chemical antimicrobials on pathogens such as Salmonella and E. coli present on cattle hides destined to slaughter. Nevertheless, organic acids appear to be the most studied group of chemical (Loretz, Stephan, \& Zweifel, 2011). The effect of organic acid sprays in reducing Salmonella load on cattle hides was studied by Mies et al. (2004). These authors sprayed cattle hides with different concentrations (2 to 6\%) of acetic and lactic acids and noted reductions in Salmonella Typhimurium previously inoculated on the hides of 2.4 to 4.8 and 1.3 to 5.1 logarithmic units, respectively. However, treating live cattle with a lactic acid solution $(0.5 \%)$ during 1 minute did not reduce the proportion of Salmonella-positive hide samples. In another study, a reduction average 
of $2 \log$ units in Salmonella and E. coli O157 loads was reported on previously inoculated cattle hides using lactic and acetic acid $\left(10 \%, 55^{\circ} \mathrm{C}\right)$ sprays (Carlson et al., 2008).

Although a variety of biological treatments are reported to be used in carcass decontamination, bacteriophages constitute the only biological treatment reported to be used in hide decontamination (Bolder, 1997; Chen et al., 2012). Some bacteriophages targeted to bacteriological pathogens namely Salmonella and E. coli O157:H7 have been already approved in United States for cattle hide decontamination, however the possibility of their utilization under commercial conditions is still being investigated (Loretz et al., 2011)

Apart from reducing the bacterial load on hides and possibly improving carcass microbiological quality, some hide decontamination interventions were found to present some disadvantages. It has been reported that treatments with water or steam increase the humidity on the surface of the treated hides (Loretz et al., 2011). This makes the skinning operations more difficult for the operator and may increase the risk of carcass contamination from the hide, especially when hide removal is carried out manually. Antic et al. (2010) reported that microbial contamination of bovine carcases during skinning was more likely to occur when the animal hide was wet. Steam treatments were also found to deteriorate the commercial quality of hides (McEvoy et al., 2003). Furthermore, animal and operator welfare problems, namely eye and skin irritation as well as corrosion of slaughtering equipment, have reportedly been associated with the use of chemical antimicrobials, particularly organic acids (Chen et al., 2012; Mies et al., 2004).

Hide decontamination, treatments appear to be an important strategy that can significantly reduce the risk of carcass contamination from soiled hides during the skinning process. However, considering existing data, it is difficult to accurately appraise their effect under normal slaughtering conditions as most of available informations derive from experimental studies. Additionally, very limited number of studied treatments concerned bacterial pathogens such as Salmonella or pathogenic E. coli. It is therefore imperative to conduct further studies to assess the effects of these interventions on major bacterial pathogens under practical slaughtering conditions. Another issue is to identify the optimal moment in the slaughtering process at which the hide decontamination treatment should be carried out under commercial conditions. The moment between stunning and sticking would be appropriate provided that the animal's unconsciousness lasts until the hide decontamination process ends. Alternatively, the moment after sticking but before hide removal would be used. In the latter case, appropriate measures should be taken so as not to contaminate the sticking wound during the hide decontamination process.

\subsubsection{Cattle Skinning}

The skinning stage is one of the slaughtering steps where microbial contamination of bovine carcasses is most likely to occur. This is due to the fact that the hide is, in most cases, heavily populated by a wide range of microorganisms that can be transferred to carcasses during skinning operations (Loretz et al., 2011). Bacterial pathogens such as Salmonella and E. coli $\mathrm{O} 157$ are also commonly isolated from hides of cattle destined to slaughter (Barham et al., 2002; Barkocy-Gallagher et al., 2003). During the skinning process, carcass contamination may occur through direct contact between the carcass and the hide or indirectly through equipment or operators contaminated by hides. Carcass contamination by airborne transfer is also possible (Antic et al., 2010).

Cattle hide removal can be carried out either manually or mechanically by means of a hide puller. The advantage of manual hide removal relies mainly in its low financial investment in equipment, but it has been found to present several disadvantages in terms of slaughter productivity and meat hygiene (Food and Agriculture Organization, 2006). These include the requirement for a very high skill level for effective hide removal without damaging both hide and carcass; the difficulty of the task and the time consumed even for a skilled operator; and a high risk of contaminating the carcass with microorganisms from the hide during the skinning process. On the other side, mechanical skinning by means of a hide puller seems to require less manual contact with the hide and consequently minimizes the risk of carcass contamination by microorganisms from operators and slaughtering equipments. Additionally, it increases the productivity of the slaughterhouse and improves the value of the hides by damaging them less. The disadvantages of mechanical skinning include the high cost of the equipment and fractures of the spinal column sometimes associated with the use of a downward hide puller. 


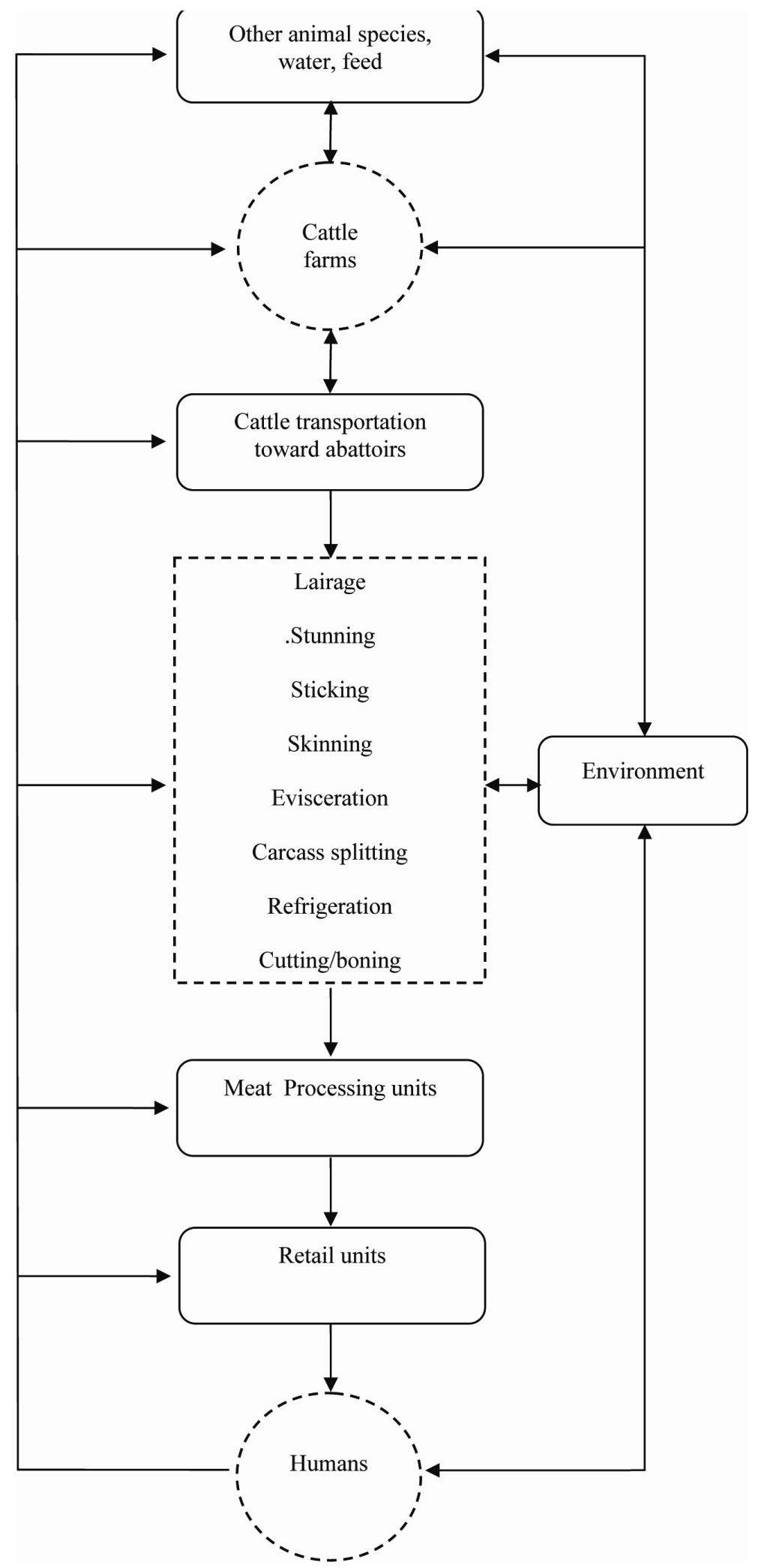

Figure 1. Potential sources and pathways for microbial contamination of bovine meat (Adapted from: Food and Agriculture Organization, 2006 and Millemann, 2008)

Peer-reviewed studies addressing the quantification of microorganisms transferred from hides to carcasses during the skinning indicate that, under commercial conditions, dressed bovine carcasses carry a very small proportion (ranging from 1.6 to $0.003 \%$ ) of the hide microflora (Arthur et al., 2004; Bacon et al., 2000). Another 
study showed that only 0.5 to $0.00002 \%$ of the hide microflora is transferred to dressed bovine carcass via direct contact (Antic et al., 2010) highlighting the importance of other transmission pathways such as indirect contamination via knives and/or hands or airborne transfers. Nevertheless, even if the reported hide-to-meat microbial transmission rates appear to be relatively low, it should be noted that the risk associated to these transmissions is still significant. In fact, carcass contamination from hides occurs regularly under commercial slaughtering conditions and the reported bacterial loads on hides are so high that proportions as low as less than $1 \%$ would constitute levels of many logarithmic units (Loretz et al., 2011). By summarizing data from numerous studies published internationally, Antic et al. (2010) reported bacterial contamination levels of 6-10 log cfu/ $/ \mathrm{cm}^{2}$ and 4.5-8 $\log \mathrm{cfu} / \mathrm{cm}^{2}$ respectively on visually dirty and clean hides from cattle destined to slaughter.

The control of carcass bacterial contamination from hides during skinning operations consists basically in preventing hide-to-meat contaminations through process hygiene means and/or the elimination microbial contaminants from hides before skinning operations by adequate treatments. Concerning the process hygiene, several studies have reported an association between the hide cleanliness and the microbiological status of dressed carcasses (McEvoy et al., 2000; McCleery et al., 2008). Thus, in many countries (including but not limited to Australia, Ireland, Finland, Norway and United Kingdom) Good Hygienic Practice programs in cattle dressing are based on the cleanliness of cattle hides. In these countries, only cattle with clean hides are slaughtered under normal conditions whereas dirty animals are either cleaned (and allowed to dry before slaughtering) or are slaughtered separately under special conditions as they are considered to present a high risk for cross contaminations (McEvoy et al., 2000). A recent study conducted in Norwegian abattoirs (Hauge, Nafstad, Røtterud, \& Nesbakken, 2012) confirmed that, under commercial conditions, carcasses from clean animals present levels of hygiene indicator bacteria (total aerobic bacteria and E. coli counts) significantly lower than these from dirty animals. Although the cleanliness of cattle hides prior to skinning presents considerable beneficial effects on the bacteriological status of dressed carcasses, it should be noted however, that these effects are not absolute. In fact, it is known that pathogenic bacteria such as E. coli $\mathrm{O} 157$ are commonly isolated from visually clean hides (Nastasijevic et al., 2008). Therefore, the selection of cattle with clean hides for slaughter should be combined with other good hygienic practices including hygiene for staff and skinning equipments as well good manufacturing practices particularly an immediate carcass trimming when any carcass contamination is suspected (Kiermeier et al., 2006; J J Sheridan, 1998). The elimination of bacterial contaminants from hides prior to skinning constitutes a promising alternative to consider. However, as presented in previous sections of the present paper, most of the existing informations on the effects of hide decontamination treatments derive from experimental studies. Further studies are therefore still needed to accurately appraise the effects of these treatments under commercial slaughtering conditions.

\subsubsection{Evisceration}

As the skinning step, evisceration constitutes a critical slaughtering stage where microbial contamination of carcasses is most likely to occur. The gastro-intestinal tract of cattle is naturally colonised by microorganisms that may be transferred to carcasses during the evisceration process (McEvoy et al., 2000). Additionally, bacterial pathogens such as Salmonella and E. coli are also frequently isolated in faeces of cattle destined to slaughter highlighting their probable presence in the digestive tract of the same animals (Rhoades et al., 2009). During the evisceration process, carcass contamination occurs by direct contact between the carcass and the gastro-intestinal contents or indirectly through soiled slaughtering equipments and staff. Contaminations may also occur during the removal of pharynx, tonsil and tongue as they are reported to be heavily contaminated by various microbial contaminants (Sheridan, 1998; Wheatley, Giotis, \& Mckevitt, 2014).

Several peer-reviewed studies indicate a significant increase of bacterial loads on carcasses during the evisceration process; however the degree of increase varies from one study to another. The observed variation could be attributed to a number of factors including the differences in experimental designs and the process hygiene that differ from one slaughterhouse to another. For example, an average increase of $0.7 \operatorname{logcfu} / \mathrm{cm}^{2}$ in Enterobacteriaceae counts was reported during the evisceration of lamb carcasses in 4 Irish abattoirs (Sierra, Sheridan, \& McGuire, 1997); whereas in Rwanda increases of 3 and $1.3 \log$ cfu/g were respectively observed in total aerobic bacteria and E. coli counts during the evisceration of cattle at a commercial abattoir (Niyonzima et al., 2013). Another Irish study reported an increase of 2-4 log in Enterobacteriaceae populations during the evisceration of pork carcasses (Wheatley et al., 2014).

The control of carcass bacterial contaminations during the evisceration process relies mainly on Good Slaughtering Practices. The techniques mostly used include the "bunging" and the "rodding". The bunging or bung tying consists in sealing the rectum and covering it with a plastic bag in order to reduce the spread of faecal material from the rectum to the carcass; whereas the rodding corresponds to sealing the oesophagus to avoid the 
spread of its content onto the carcass (McEvoy, Sheridan, Blair, \& McDowell, 2004). These techniques are effective in reducing the risk of bacterial transfers during the evisceration. Nesbakken et al. (1994) reported that bunging reduced significantly the occurrence of Yersinia enterocolitica on pig carcasses. Furthermore, the introduction of that technique in Norwegian pork abattoirs resulted in decreasing the incidence of Yersiniosis by $25 \%$ in the population (Sheridan, 1998). Similarly, special attention must also be paid to the training of staff on Good Hygienic Practices as well as on the sanitation of slaughtering equipments particularly knives to minimize the risk of cross contaminations. Bolton et al. (2002) recommend sanitizing knives by a two-knife system that consists in the utilization of one knife while the other is being sanitized in hot water at $82^{\circ} \mathrm{C}$ or above.

Despite the reported increases in bacterial load on carcasses during their evisceration, some authors indicate that the existing measures including rectum and oesophagus sealing, intact removal of visceral contents and an appropriate training of staff in Good Hygienic Practices could reduce the risk of carcass contamination from viscera to the point where they do not contribute significantly to the overall contamination of the carcass (McEvoy et al., 2000; Wheatley et al., 2014).

\subsubsection{Carcass Splitting}

The carcass splitting stage is not generally considered as a major source of contamination (Wong et al., 2002). However, the splitting saw as well as other slaughtering equipment can be contaminated with pathogenic bacteria such as Salmonella and E. coli and may contribute to their spread to several carcasses. In a study conducted in 4 European countries, Hald et al. (2003) reported that 9.4\% of 384 carcass splitter machines were contaminated with Salmonella during the slaughtering process. In addition, Warriner et al. (2002) demonstrated that $E$. coli and potential enteric pathogens can be transferred between pork carcasses through the splitting saw. Therefore, cleaning and disinfection of the splitting saw should be carried out after splitting each carcass in order to reduce the risk of cross contaminations. The European regulations recommend disinfecting the splitting saw after splitting each animal using water at $82^{\circ} \mathrm{C}$ or above or using another method with an equivalent effect (European Commission, 2004).

Although adherence to Good Hygiene Practices in abattoirs improves the microbiological quality of the meat significantly, it is generally recognized that contamination of meat is unavoidable during the cattle slaughtering process (McCann et al., 2006). Therefore, carcass decontamination before refrigeration appears as a corrective measure to restore the bacterial load of carcasses to the acceptable range.

\subsubsection{Carcass Decontamination Treatments}

Various treatments including physical, chemical and biological methods applied alone or in combination have been identified to reduce the levels of bacterial load on carcasses. In this section majors carcass decontamination treatments as well as their respective effects on the bacterial load of carcasses are discussed.

The physical decontamination treatments mostly reported for carcasses include hot water washes and application of steam. These treatments are generally carried out in special cabinets where carcasses are splayed with water or steam at controlled pressure and temperature. Carcass sprays with hot water were found to lower significantly the bacterial load on treated carcasses. However, the reduction rates reported were found to be dependent of experimental factors such as the temperature, pressure and the duration of the treatment (Loretz et al., 2011). The effectiveness of carcass decontamination by hot water was demonstrated by Bosilevac et al. (2006). These authors conducted a study in a commercial abattoir and reported $2.7 \mathrm{log}$ reductions in both aerobic plate counts and Enterobacteriaceae counts on pre-evisceration bovine carcasses washed in a cabinet with water at $74^{\circ} \mathrm{C}$ for 5.5 seconds. The prevalence of $E$. coli $\mathrm{O} 157$ was also reduced by $81 \%$ in treated carcasses. The decontamination of carcasses with steam was reported to yield bacterial reductions comparable to these obtained with hot water spays. However, the treatments with steam presents an advantage of reaching cavities and crevices of carcasses that are generally inaccessible to hot water (Hugas \& Tsigarida, 2008). One of the side effects reportedly associated with carcass decontamination treatments by steam or hot water is the change in the carcass colour after a prolonged treatment. McCann et al. (2006) reported a cooked appearance on the surface of carcasses having undergone a steam decontamination treatment of 10 seconds or longer. Furthermore, weight gain resulting from water absorption by treated carcasses generally reported in hot water decontamination treatments may be perceived as a fraud by meat consumers (EFSA, 2010).

Organic acid sprays, namely acetic, citric and lactic acids are the most-reported chemical decontamination methods used on beef carcasses. They are known to reduce the number and prevalence of food borne pathogens and the microbial load on meat carcasses (Huffman, 2002), but their efficacy depends on the type of meat tissue, the type and load of initial microbial contamination, as well as the $\mathrm{pH}$, concentration and temperature of the organic acid solution (Hugas \& Tsigarida, 2008). Various studies conducted under laboratory conditions showed 
that spraying inoculated bovine carcasses with acetic or citric acid yielded bacterial reductions varying between 0.7 and $4.9 \operatorname{logs}$ for aerobic bacteria, non pathogenic E. coli, E. coli O157:H7 and Salmonella (Loretz et al., 2011). However, lower reductions are generally reported in studies conducted under commercial conditions. This could be due to lower acid concentrations used in respect to meat quality and staff welfare considerations (Chen et al., 2012). By spraying acetic acid (2.5\%) to bovine carcasses prior to chilling Algino et al. (2007) reported reductions of coliforms, Enterobacteiaceae and E. coli levels ranging from 0.6 to 1.4 logs. In a study by Barboza de Martinez et al. (2002) spraying carcasses at the end of slaughter by lactic acid (1.5\%) yielded reductions of $0.5,1.8$ and $0.6 \operatorname{logs}$, respectively, for aerobic bacteria, coliforms and E. coli. In another study, lactic acid (2\%; $42^{\circ} \mathrm{C}$ ) spraying of pre-eviscerated bovine carcasses was reported to reduce the prevalence of $E$. coli $\mathrm{O} 157: \mathrm{H} 7$ by $35 \%$ as well as aerobic bacteria and Enterobacteriaceae counts by respectively 1.6 and $1.0 \operatorname{logs}$ (Bosilevac et al., 2006). Other chemicals such as chlorine, trisodium phosphate, acidified sodium chlorite and peroxyacids are also used for meat decontamination but to a lesser extent. Generally, the use of these substances leads to $1-1.5 \log$ reductions in foodborne pathogens such as Salmonella and E. coli O157 (Hugas \& Tsigarida, 2008). A number of drawbacks have however been reportedly associated to the chemical decontamination of carcases especially by organic acids. These include staff welfare problems such as eye or skin irritations and the corrosion of slaughtering equipments (Chen et al., 2012; Mies et al., 2004).

Reported biological treatments for meat decontamination include the use of bacteriocins and bacteriophages. Bacteriocins are anti-microbial proteinaceous compounds produced by some bacteria. The most widely known bacteriocin is nisin, which is produced by Lactobacillus lactis subsp. lactis and is effective against Gram-positive bacteria. Nisin is used as a preservative agent in foods like cheese but its use in carcass decontamination has been limited by a number of factors, namely its deficient inhibitory effect on Gram-negative bacteria, low level of production in vivo and likely inactivation of its effect due to interactions with other food components (Bolder, 1997; Chen et al., 2012). Nevertheless, combinations of nisin and other treatments have been reported to reduce microbial contamination on carcasses. Barboza de Martinez et al. (2002) reported that a combination of nisin and lactic acid sprays under commercial conditions reduced aerobic bacteria, coliforms and E. coli populations on carcasses by 2.0, 2.2, and more than $1.0 \mathrm{log}$, respectively, whereas treatment with nisin alone reduced bacterial levels by less than $0.2 \mathrm{log}$. The use of bacteriophages has also been reported to present a number of benefits as an alternative biocontrol method. These include their high host specificity and lack of effect on the organoleptic qualities of the food as well as their ability to survive under commercial processing procedures (Hugas \& Tsigarida, 2008). However, their use in food decontamination is still limited by factors such as the potential development of resistance in targeted bacteria (Chen et al., 2012). The use of E. coli O157:H7 and Salmonella targeted bacteriophages for cattle hide decontamination has already been approved in the USA. However, further investigations to address their efficacy under long-term commercial conditions and their possible utilization for carcass decontamination are still required (Loretz et al., 2011).

Although obtaining bovine carcasses free of pathogenic bacteria and with low microbial contamination appears to be a shared goal of all countries, carcass decontamination policies vary from one country to another. In the USA, for example, a number of carcass decontamination treatments are allowed and commonly used in cattle slaughterhouses. These include physical interventions such as hot water or steam spraying and chemical treatment with organic acids, namely lactic and acetic acids (Chen et al., 2012). Contrary to this, in Europe important efforts have been put into the application of Good Manufacturing Practices throughout the entire meat production line, and for many years carcass decontamination treatments in the European Union were limited to the use of clean or potable water. The current European regulation (European Commission, 2004) allows the use of substances other than water for the removal of surface bacterial contamination from meat; however, the European Food Safety Authority (EFSA) must provide a chemical and microbiological risk assessment before the European commission authorizes the use of such substances (Hugas \& Tsigarida, 2008). Currently, no chemical substance has yet been approved for decontamination of beef carcasses within the European Union (EFSA, 2014a).

Carcass decontamination treatments constitute a potential control measure to reduce the levels of bacterial and pathogen loads on carcasses. However, available informations indicate a wide variability in bacterial reduction yields as most of data results from studies conducted under different conditions. Thus, studies to compare the effectiveness of different treatments under the same conditions would be of valuable importance to identify the cost-effective interventions to be used in cattle slaughterhouses. Furthermore, the risk, in some abattoir, to rely only on the carcass decontamination step and abandon existing good hygienic and manufacturing practices in previous slaughtering stages need to be considered before the adoption of such interventions. 


\subsubsection{Carcass Refrigeration}

Apart from meat maturation purposes, refrigeration of carcasses after the slaughtering process is performed to inhibit the growth of spoilage and/or pathogenic bacteria that could still be on the carcasses and consequently increase their shelf-life (Dave \& Ghaly, 2011). Carcass refrigeration is generally carried in two phases including the rapid chilling phase consisting in rapidly reducing the carcass temperature and a second phase of cold storage intended to maintain the low temperature of carcasses. Different methods of carcass chilling were thoughtfully reviewed by Savell et al. (2005) and are not further developed in this paper. In commercial slaughterhouses, carcasses are generally chilled for 48-72 hours before their transfer in the boning hall. Nevertheless, the duration of carcass chilling may be extended beyond 72 hours to improve the quality of meat. This process is referred to as aging (EFSA, 2014b). The inhibition of bacterial growth on carcasses at refrigeration temperatures is a consequence of low-temperature stress undergone by microorganism. In fact, as the temperature decreases, the bacterial lag phase extends whereas the growth rate decreases and the ultimate cell numbers may decrease (Beales, 2004; N J Russell et al., 1995).

Although bacterial growth on carcasses is known to be inhibited at refrigeration temperatures (Korsak, Clinquart, \& Daube, 2004; Russell, 2002), several published studies indicate increases in levels of bacterial loads on refrigerated carcasses. In a study conducted in a commercial abattoir, Bolton et al. (2002) reported an increase in total viable bacterial counts from 3.8 to $4.5 \log \mathrm{cfu} / \mathrm{cm}^{2}$ on carcasses at the refrigeration stage. Another study conducted on poultry carcasses showed that after 9 days of storage, Salmonella loads were slightly reduced (by less than $1 \log$ unit) on carcasses refrigerated at 2 and $6^{\circ} \mathrm{C}$ whereas in carcasses refrigerated at $8^{\circ} \mathrm{C}$ Salmonella number increased by $1.5 \log$ units (Jiménez, Tiburzi, Salsi, Moguilevsky, \& Pirovani, 2009).

Microbial growth on carcasses under refrigeration is mainly attributable to the temperatures of chilling equipments that are not sufficiently low to inhibit the microbial growth and/or to intermittent rupture of the cold chain. In fact, bacterial pathogens such as Salmonella may multiply to hazardous levels during periods of temperature abuse (Delhalle et al., 2009; Wong et al., 2002). Thus, slaughterhouses should be equipped with chilling equipments capable to rapidly decrease and maintain low the temperature of carcasses during the entire refrigeration period. In European Union countries for example, the carcass temperature must be decreased to maximum $7^{\circ} \mathrm{C}$ in the first 24 hours of refrigeration (European Commission, 2004). Additionally, trough cross-contaminations, microorganisms present on carcasses under refrigeration or on chilling equipments may get disseminated to other carcasses and proliferate when the environment become favourable to their growth (for example during temperature abuses). Published studies indicate that bacterial pathogens can survive on surfaces of refrigerators (Jackson, Blair, McDowell, Kennedy, \& Bolton, 2007) or on chilling evaporators (Evans, Russell, James, \& Corry, 2004) and pose a cross-contamination risk to the refrigerated foods. This highlights the need for a regular cleaning and disinfection of chilling rooms and/or equipments in the slaughterhouse.

The refrigeration of carcasses constitutes a determinant slaughtering stage influencing the final bacterial load on carcasses. However, despite the exiting control measures (including adequate chilling equipments, the regular monitoring of the temperature of carcasses and the mastery of cross-contaminations through an effective appliance to Good Hygienic Practices) that have proven their effectiveness in significantly reducing the risk of bacterial/pathogen growth on carcasses under refrigeration (Delhalle et al., 2009); in some slaughterhouses, bacterial growth is still being reported on refrigerated carcasses probably due to the failure in applying adequate control measures. It is thus imperative for slaughterhouses to deploy all material, technical and financial means required to control the bacterial growth on carcasses at this critical stage of slaughter.

\subsection{Post Slaughter Contamination of Bovine Meat}

The post slaughter section of the meat chain comprises a series of sub-stages (including cutting/boning, transportation of carcasses or meat cuts, meat storage, manufacture of meat products, retail, and eventually cooking) at which contamination of meat may occur. In this section majors sources of post slaughter meat contamination by pathogenic bacteria and their respective control measures are reviewed.

At the end of the slaughtering process carcasses are generally cut in special meat pieces (cutting) and separated from bones (boning) for industrial and commercial utilisations. The cutting and boning of carcasses may take place in the slaughterhouse or in specialised plants. The cutting and boning operations are generally performed on refrigerated carcasses however boning of non refrigerated carcasses (hot boning) is also possible (Røtterud et al., 2006). Even if hot boning presents a number of advantages including a reduced cost and fewer requirements in chilling equipments and space (Pinto Neto, Beraquet, \& Cardoso, 2013) it is rarely used in European countries. This is mainly due to a possible proliferation of pathogenic bacteria on processed meat and a reduced shelf life of subsequent vacuum packed meat (Yang, Balamurugan, \& Gill, 2011). A recent report from the European Food 
Safety Authority indicate that the surface temperature of boned beef cuts from chilled carcasses decreases to $8^{\circ} \mathrm{C}$ in few hours whereas the temperature of hot boned and vacuum packed meat pieces may remain at $25^{\circ} \mathrm{C}$ for many hours; creating favourable conditions for the proliferation of spoilage and pathogenic microorganisms (EFSA, 2014b). Data from published studies indicate that bacterial/pathogen loads on carcasses may significantly increase during the cutting/boning operations even in slaughterhouses where cold boning is practicised. In a study conducted in an Irish beef abattoir, McEvoy et al. (2004) reported increases of 2.3 and 2.1 $\log \mathrm{cfu} / \mathrm{cm}^{2}$ respectively for total viable bacteria and Enterobacteriaceae counts on the inside round of carcasses during the cutting/boning operations. Similar increases were also reported in E. coli numbers during the boning of beef carcasses (Gill, McGinnis, \& Bryant, 2001). Increases in bacterial/pathogen numbers following the cutting and boning operations could be associated to cross-contaminations. During these operations, carcasses or meat pieces of various origins and different contamination levels are handled in close proximity, creating numerous opportunities for cross-contamination or spread of pathogenic bacteria (Wong et al., 2002). Various origins of microbial contamination during cutting/boning were reported in literature. These include carcasses or meat pieces to be processed (McEvoy et al., 2004); meat cutting/boning equipments such as knives, meat conveyors or cutting boards (Gill, Badoni, \& McGinnis, 1999; Gill et al., 2001; Jiménez et al., 2009) and soiled surfaces or operators (Sheridan, Lynch, \& Harrington, 1992). One of the measures to prevent cross contaminations resulting from contaminated carcasses or meat pieces would be to identify the most contaminated raw materials and to process them separately preferably at the end of the production (Koohmaraie et al., 2012). Contaminations from equipments can be mastered through a regular cleaning and disinfection of equipments and surfaces whereas effective training of staff on Good Hygienic Practices could help in preventing contaminations from personnel (Delhalle et al., 2009). The working temperature constitutes another factor influencing bacterial growth on meat during the cutting/boning operations. In fact, during these operations the temperature of processed meat increases and this would favour the growth of existing microbial populations. It is therefore recommended to carry out boning operations under refrigerated conditions. In some commercial abattoirs, the boning hall is refrigerated at $10-12^{\circ} \mathrm{C}$ (EFSA, 2014b; McEvoy et al., 2004).

Although temperature abuse is reportedly the main factor associated to bacterial load increases on carcasses or meat pieces during transportation and storage (Delhalle et al., 2009; Wong et al., 2002), cross-contaminations originating from chilling equipments or personnel are also significant contributors to the ultimate bacterial load of meat (Evans et al., 2004; Jackson et al., 2007; Sheridan et al., 1992). Thus, it is imperative to prevent cross contamination through an effective and regular sanitization of chilling rooms and meat transportation vehicles. Additionally, personnel involved in the loading of meat transportation vehicles should be educated in good hygiene practices. On the other side, the regular monitoring of temperatures in chilling rooms and meat transportation vehicles could contribute significantly in reducing the risk of temperature abuses occurring during meat storage and transportation (Savell et al., 2005). Recent published studies indicate that meat transportation vehicles with a chilling capacity comparable to the one of conventional chilling rooms are commercially available. Most of these vehicles are designed for longer distances and can decrease the core temperature of bovine carcasses from approximately $20^{\circ} \mathrm{C}$ at the loading time to $7^{\circ} \mathrm{C}$ or lower after 48 hours. Additionally, these vehicles are equipped with apparatus to continuously monitor the temperature of meat during the transportation (EFSA, 2014b).

As in previous stages of the meat chain, cross-contamination from equipments, personnel or the working environment are likely to occur during the manufacture of meat products if appropriate control measures are not effectively applied (Roels et al., 1997; Wong et al., 2002). Nevertheless, microbial contaminants from incorporated non-meat ingredients as well as contaminations associated to the manufacture method used, appear to be specific to this particular stage of the meat chain. The grinding of meat for example, would result in the dissemination of microorganisms previously localised at the surface of meat pieces in the entire batch of minced meat (Gould et al., 2011). As the meat temperature increases during grinding operations due to friction movements, these microorganisms may proliferate in relatively short period resulting in bacterial number increases in minced meat (Heinz \& Hautzinger, 2007). A number of preservative treatments (including thermal interventions, smoking, curing etc.) are commonly used in meat processing to enhance the bacteriological stability of meat products and consequently increase their shelf-life. These interventions, generally based on the control of the temperature, $\mathrm{pH}$, water activity, microbial competition/interaction and oxido-reduction potential, were found to significantly reduce the bacterial/pathogen load in meat (Chen et al., 2012; Hugas \& Tsigarida, 2008; Loretz et al., 2011). However, as their preservative effects depend also on the initial bacterial numbers in meat; it is crucial for meat processors to assure that the used raw materials are of good microbiological quality (Wong et al., 2002). Another important measure would be to decide the fate of raw materials according to their microbiological quality. In some commercial meat processing plants, heavily contaminated raw materials are 
generally reserved for the manufacture of meat products destined to undergo a heat treatment (Koohmaraie et al., 2012; McCleery et al., 2008; McEvoy et al., 2000; Nastasijevic et al., 2008).

At the retail level, temperature conditions are reportedly an important factor influencing the final microbiological quality and safety of meat products (Delhalle et al., 2009). Several published studies indicate a wide variation in meat product temperatures within retail cabinets but most of the data are simply indicative of the product temperature at the time and place of the study and do not address conditions that would dynamically influence the temperature changes (Nychas, Skandamis, Tassou, \& Koutsoumanis, 2008). Nevertheless, it is recognised that displayed meat products in retail cabinet must be at temperatures sufficiently low (generally below $4^{\circ} \mathrm{C}$ ) to inhibit the growth of spoilage or pathogenic microorganisms (Wong et al., 2002). It is therefore imperative to regularly monitor the temperature of display cases to prevent temperature abuses during meat storage. Furthermore, appropriate control measures must be applied to prevent cross contaminations from equipments, personnel or working environment in retail establishment where meat processing activities such as cutting or grinding are carried out (Gould et al., 2011). The retail level represents an important stage of the meat chain in regard with the final quality and safety of meat products as it constitutes the last "check point" where contaminated products can be identified before their consumption particularly for ready-to-eat meat products (Wong et al., 2002).

The last section of the meat chain related to the transportation, storage and cooking by the consumer appears to be less studied although it is the most important in regards with the food safety aspects of meat products. This is due to the difficulties in collecting data concerning the mode and the duration of meat transportation toward the consumer's household, temperature conditions in domestic refrigerator and freezers, durations of storage before consumption as well as consumer's cooking habits (Nychas et al., 2008). However, it is recognised that the cooking stage is the last line of defence of consumers against Salmonella and pathogenic E. coli infections attributable to bovine meat (Korsak et al., 2004; Mainil \& Daube, 2005). These pathogens are generally destroyed in foods at conventional pasteurisation temperatures. In beef, Salmonella is reported to have a decimal reduction time (D-value) of 0.53 minutes $\left(\mathrm{z}=5^{\circ} \mathrm{C}\right)$ at $65^{\circ} \mathrm{C}$ (Juneja et al., 2001; Korsak et al., 2004) whereas $E$. coli $\mathrm{O} 157: \mathrm{O} 7$ presents a $\mathrm{D}$-value of 0.39 minutes $\left(\mathrm{z}=6^{\circ} \mathrm{C}\right)$ at the same temperature (Juneja, Snyder, \& Marmer, 1997). It is therefore recommended to cook meat until the internal temperature reaches a minimal temperature of $70^{\circ} \mathrm{C}$ to assure a thermal destruction of these pathogens in meat as most of the reported Salmonella and E. coli O157:H7 outbreaks attributable to meat were found to be associated to the ingestion of raw or undercooked meat products (Abong'o \& Momba, 2009; Greig \& Ravel, 2009; Roels et al., 1997).

\section{Conclusion}

Despite a large number of control measures along the meat chain, meat contaminations by Salmonella and pathogenic E-coli remain a serious public health problem in humans. In the pre-slaughter stages of the meat chain, difficulties in identifying asymptomatic shedders constitute the main obstacle to the control of the infection spread in live animals. Further studies are therefore needed to identify cost-effective techniques and approaches to diagnose asymptomatic carriers in cattle herd before animal transportation to abattoirs. During the slaughtering process, the skinning and evisceration operations appears to be the most critical stages for carcass contamination. Thus Good Manufacturing Practices in accordance with HACCP principles must be strictly applied in commercial slaughterhouses to reduce the risk of carcass contamination at those specific stages. The decontamination of carcasses has also shown a potential in reducing pathogen numbers on carcasses prior to chilling, even if its utilisation in some countries is still limited by a number of factors including the cost of installations, the commercial quality of treated carcasses as well as the risk of relying only on the carcass decontamination step and reduce efforts devoted to Good Hygiene and Manufacturing Practices in previous slaughtering stages. Along post-slaughter stages of the chain, handling, time and temperature are the main factors influencing the microbial contamination of meat. Therefore application of appropriate GMP and GHP by meat processing plants is of great importance to prevent cross-contaminations during cutting/boning, processing, transportation and retail of meat products. Similarly, the cold chain must be respected at all stages of meat distribution. Although all stages of the bovine meat chain are of significant relevance in regard to the ultimate bacterial contamination of meat, the cooking step constitutes the most important stage to assure the safety of beef at consumption. In fact, the cooking step is the last stage of the meat chain at which Salmonella and pathogenic E. coli can be completely destroyed. 


\section{References}

Abong'o, B. O., \& Momba, M. N. B. (2009). Prevalence and characterization of Escherichia coli O157:H7 isolates from meat and meat products sold in Amathole District, Eastern Cape Province of South Africa. Food Microbiology, 26(2), 173-6. http://dx.doi.org/10.1016/j.fm.2008.10.001

Alexa, P., Konstantinova, L., \& Sramkova-Zajakova, Z. (2011). Faecal shedding of verotoxigenic Escherichia coli in cattle in the Czech Republic. Veterinarni Medicina, 56(4), 149-155.

Algino, R. J., Ingham, S. C., \& Zhu, J. (2007). Survey of antimicrobial effects of beef carcass intervention treatments in very small state-inspected slaughter plants. Journal of Food Science, 72(5), M173-9. http://dx.doi.org/10.1111/j.1750-3841.2007.00386.x

Anil, M. H., Love, S., Helps, C. R., Mckinstry, J. L., Brown, S. N., Philips, A., ... Harbour, D. (2001). Jugular venous emboli of brain tissue induced in sheep by the use of captive bolt guns. The Veterinary Record, 148, 619-620.

Antic, D., Blagojevic, B., Ducic, M., Nastasijevic, I., Mitrovic, R., \& Buncic, S. (2010). Distribution of microflora on cattle hides and its transmission to meat via direct contact. Food Control, 21(7), 1025-1029. http://dx.doi.org/10.1016/j.foodcont.2009.12.022

Arthur, T. M., Bosilevac, J. M., Brichta-Harhay, D. M., Guerini, M. N., Kalchayanand, N., Shackelford, S. D., ... Koohmaraie, M. (2007). Transportation and lairage environment effects on prevalence, numbers, and diversity of Escherichia coli 0157:H7 on hides and carcasses of beef cattle at processing. Journal of Food Protection, 70(2), 280-6.

Arthur, T. M., Bosilevac, J. M., Nou, X., Shackelford, S. D., Wheeler, T. L., Kent, M. P., ... Koohmaraie, M. (2004). Escherichia coli O157 prevalence and enumeration of aerobic bacteria, Enterobacteriaceae, and Escherichia coli $\mathrm{O} 157$ at various steps in commercial beef processing plants. Journal of Food Protection, 67(4), 658-65.

Arthur, T. M., Brichta-Harhay, D. M., Bosilevac, J. M., Kalchayanand, N., Shackelford, S. D., Wheeler, T. L., \& Koohmaraie, M. (2010). Super shedding of Escherichia coli O157:H7 by cattle and the impact on beef carcass contamination. Meat Science, 86(1), 32-7. http://dx.doi.org/10.1016/j.meatsci.2010.04.019

Bacon, R. T., Belk, K. E., Sofos, J. N., Clayton, R. P., Reagan, J. O., \& Smith, G. C. (2000). Microbial Populations on Animal Hides and Beef Carcasses at Different Stages of Slaughter in Plants Employing Multiple-Sequential Interventions for Decontamination. Journal of Food Protection, 63, 1080-1086.

Baird, B. E., Lucia, L. M., Acuff, G. R., Harris, K. B., \& Savell, J. W. (2006). Beef hide antimicrobial interventions as a means of reducing bacterial contamination. Meat Science, 73(2), 245-248. http://dx.doi.org/10.1016/j.meatsci.2005.11.023

Barboza de Martinez, Y., Ferrer, K., \& Salas, E. M. (2002). Combined effects of lactic acid and nisin solution in reducing levels of microbiological contamination in red meat carcasses. Journal of Food Protection, 65, 1780-1783.

Barham, A. R., Barham, B. L., Johnson, A. K., Allen, D. M., Blanton, J. R., \& Miller, M. F. (2002). Effects of the transportation of beef cattle from the feedyard to the packing plant on prevalence levels of Escherichia coli O157 and Salmonella spp. Journal of Food Protection, 65(2), 280-283.

Barkocy-Gallagher, G. a, Arthur, T. M., Rivera-Betancourt, M., Nou, X., Shackelford, S. D., Wheeler, T. L., \& Koohmaraie, M. (2003). Seasonal prevalence of Shiga toxin-producing Escherichia coli, including O157:H7 and non-O157 serotypes, and Salmonella in commercial beef processing plants. Journal of Food Protection, 66(11), 1978-86.

Beach, J. C., Murano, E. A., \& Acuff, G. R. (2002). Prevalence of Salmonella and Campylobacter in beef cattle from transport to slaughter. Journal of Food Protection, 65(11), 1687-1693.

Beales, N. (2004). Adaptation of Microorganisms to Cold Temperatures, Weak Acid Preservatives, Low pH, and Osmotic Stress: A Review. Comprehensive Reviews in Food Science and Food Safety, 3(1), 1-20. http://dx.doi.org/10.1111/j.1541-4337.2004.tb00057.x

Birk, T., Kristensen, K., Harboe, A., Hansen, T. B., Ingmer, H., De Jonge, R., ... Aabo, S. (2012). Dietary Proteins Extend the Survival of $<\mathrm{I}>$ Salmonella $</ \mathrm{I}>$ Dublin in a Gastric Acid Environment. Journal of Food Protection, 75(2), 353-358. http://dx.doi.org/10.4315/0362-028X.JFP-11-132 
Blaser, M. J., \& Newman, L. S. (1982). A review of human salmonellosis: I. Infective dose. Reviews of Infectious Diseases, 4(6), 1096-106.

Bolder, N. (1997). Decontamination of meat and poultry carcasses. Trends in Food Science and Technology, 8, 221-227.

Bolton, D. J., Pearce, R. a, Sheridan, J. J., Blair, I. S., McDowell, D. a, \& Harrington, D. (2002). Washing and chilling as critical control points in pork slaughter hazard analysis and critical control point (HACCP) systems. Journal of Applied Microbiology, 92(5), 893-902.

Bosilevac, J. M., Guerini, M. N., Kalchayanand, N., \& Koohmaraie, M. (2009). Prevalence and characterization of salmonellae in commercial ground beef in the United States. Applied and Environmental Microbiology, 75(7), 1892-1900. http://dx.doi.org/10.1128/AEM.02530-08

Bosilevac, J. M., Nou, X., Barkocy-Gallagher, G. a, Arthur, T. M., \& Koohmaraie, M. (2006). Treatments using hot water instead of lactic acid reduce levels of aerobic bacteria and Enterobacteriaceae and reduce the prevalence of Escherichia coil 0157:H7 on preevisceration beef carcasses. Journal of Food Protection, 69(8), 1808-13.

Bosilevac, J. M., Shackelford, S. D., Brichta, D. M., \& Koohmaraie, M. (2005). Efficacy of ozonated and electrolyzed oxidative waters to decontaminate hides of cattle before slaughter. Journal of Food Protection, 68(7), 1393-1398.

Buncic, S., McKinstry, J., Reid, C. -., \& Anil, M. . (2002). Spread of microbial contamination associated with penetrative captive bolt stunning of food animals. Food Control, 13, 425-430. http://dx.doi.org/10.1016/S0956-7135(01)00054-8

Carlson, B. A., Geornaras, I., Yoon, Y., Scanga, J. a, Sofos, J. N., Smith, G. C., \& Belk, K. E. (2008). Studies to evaluate chemicals and conditions with low-pressure applications for reducing microbial counts on cattle hides. Journal of Food Protection, 71(7), 1343-1348.

Carlson, B. A., Ruby, J., Smith, G. C., Sofos, J. N., Bellinger, G. R., Warren-Serna, W., ... Belk, K. E. (2008). Comparison of antimicrobial efficacy of multiple beef hide decontamination strategies to reduce levels of Escherichia coli O157 : H7 and Salmonella . Journal of Food Protectionn, 71(11), 2223-7.

Carney, E., O’Brien, S. B., Sheridan, J. J., McDowell, D. a, Blair, I. S., \& Duffy, G. (2006). Prevalence and level of Escherichia coli $\mathrm{O} 157$ on beef trimmings, carcasses and boned head meat at a beef slaughter plant. Food Microbiology, 23(1), 52-9. http://dx.doi.org/10.1016/j.fm.2004.12.001

Castillo, A., Dickson, J. S., Clayton, R. P., Lucia, L. M., \& Acuff, G. R. (1998). Chemical dehairing of bovine skin to reduce pathogenic bacteria and bacteria of fecal origin. Journal of Food Protection, 61(5), 623-625.

Chen, J. H., Ren, Y., Seow, J., Liu, T., Bang, W. S., \& Yuk, H. G. (2012). Intervention Technologies for Ensuring Microbiological Safety of Meat: Current and Future Trends. Comprehensive Reviews in Food Science and Food Safety, 11, 119-132. http://dx.doi.org/10.1111/j.1541-4337.2011.00177.x

Coia, J. E. (1998). Clinical, microbiological and epidemiological aspects of Escherichia coli O157 infection. FEMS Immunology and Medical Microbiology, 20(1), 1-9.

Daly, D. J., Prendergast, D. M., Sheridan, J. J., Blair, I. S., \& Mcdowell, D. A. (2002). Use of a Marker Organism To Model the Spread of Central Nervous System Tissue in Cattle and the Abattoir Environment during Commercial Stunning and Carcass Dressing. Applied and Environmental Microbiology, 68(2), 791-798. http://dx.doi.org/10.1128/AEM.68.2.791

Dave, D., \& Ghaly, A. E. (2011). Meat Spoilage Mechanisms and Preservation Techniques: A Critical Review. American Journal of Agricultural and Biological Sciences, 6(4), 486-510.

Delhalle, L., Saegerman, C., Farnir, F., Korsak, N., Maes, D., Messens, W., ... Daube, G. (2009). Salmonella surveillance and control at post-harvest in the Belgian pork meat chain. Food Microbiology, 26, 265-71. http://dx.doi.org/10.1016/j.fm.2008.12.009

Doulgeraki, A. I., Ercolini, D., Villani, F., \& Nychas, G.-J. E. (2012). Spoilage microbiota associated to the storage of raw meat in different conditions. International Journal of Food Microbiology, 157(2), 130-41. http://dx.doi.org/10.1016/j.ijfoodmicro.2012.05.020

Duffy, G., Cummins, E., Nally, P., O’ Brien, S., \& Butler, F. (2006). A review of quantitative microbial risk assessment in the management of Escherichia coli O157:H7 on beef. Meat Science, 74(1), 76-88. http://dx.doi.org/10.1016/j.meatsci.2006.04.011 
Edrington, T. S., Hurne, M. E., Looper, M. L., Schultz, C. L., Fitzgerald, a. C., Callaway, T. R., ... Nisbet, D. J. (2004). Variation in the faecal shedding of Salmonella and E. coli O157:H7 in lactating dairy cattle and examination of Salmonella genotypes using pulsed-field gel electrophoresis. Letters in Applied Microbiology, 38(5), 366-372. http://dx.doi.org/10.1111/j.1472-765X.2004.01495.x

EFSA. (2004). Welfare aspects of animal Stunning and killing methods: Scientific Report of the Scientific Panel for Animal Health and Welfare. Retrieved May 26, 2014, from www.efsa.europa.eu/en/scdocs/doc/45.pdf

EFSA. (2010). Scientific Opinion on the safety and efficacy of using recycled hot water as a decontamination technique for meat carcasses. EFSA Journal, 8(9), 1-69. http://dx.doi.org/10.2903/j.efsa.2010.1827.

EFSA. (2014a). Decontamination of carcasses. Decontamination of carcasses. Retrieved May 26, 2014, from http://www.efsa.europa.eu/en/topics/topic/decontamination.htm

EFSA. (2014b). Scientific Opinion on the public health risks related to the maintenance of the cold chain during storage and transport of meat. Part 1 (meat of domestic ungulates). EFSA Journal, 12(3), 1-81. http://dx.doi.org/10.2903/j.efsa.2014.3601

EFSA and ECDC. (2013a). The European Union Summary Report on antimicrobial resistance in Antimicrobial resistance in zoonotic and indicator bacteria from humans, animals and food in the European Union in 2011. EFSA Journal, 11(5), 3196. http://dx.doi.org/10.2903/j.efsa.2013.3196

EFSA and ECDC. (2013b). The European Union Summary Report on Trends and Sources of Zoonoses, Trends and Sources of Zoonoses, Zoonotic Agents and Food-borne Outbreaks in 2011. EFSA Journal, 11(4), 3129. http://dx.doi.org/10.2903/j.efsa.2013.3129

EFSA and ECDC. (2014). The European Union Summary Report on Trends and Sources of Zoonoses, Zoonotic Agents and Food-borne Outbreaks in 2012. EFSA Journal, 12(2), 3547. http://dx.doi.org/10.2903/j.efsa.2014.3547

European Commission. (2004). Regulation (EC) No 853/2004 of the European Parliament and of the Council of 29 April 2004 laying down specific hygiene rules for food of animal origin. Official Journal of the European Union, L139(30 April 2004), 22-82.

European Commission. (2005). Regulation No 2073/2005 of 15 November 2005 on microbiological criteria for foodstuffs. Official Journal of the European Union, L338, 1-26.

Eustace, I., Midgley, J., Giarrusso, C., Laurent, C., Jenson, I., \& Sumner, J. (2007). An alternative process for cleaning knives used on meat slaughter floors. International Journal of Food Microbiology, 113(1), 23-27. http://dx.doi.org/10.1016/j.ijfoodmicro.2006.06.034

Evans, J. a., Russell, S. L., James, C., \& Corry, J. E. L. (2004). Microbial contamination of food refrigeration equipment. Journal of Food Engineering, 62(3), 225-232. http://dx.doi.org/10.1016/S0260-8774(03)00235-8

Fegan, N., Vanderlinde, P., Higgs, G., \& Desmarchelier, P. (2005). A study of the prevalence and enumeration of Salmonella enterica in cattle and on carcasses during processing. Journal of Food Protection, 68(6), 1147-53.

Ferguson, D. M., \& Warner, R. D. (2008). Have we underestimated the impact of pre slaughter stress on meat quality in ruminants? Meat Science, 80(1), 12-19. http://dx.doi.org/10.1016/j.meatsci.2008.05.004.

Fitzgerald, a. C., Edrington, T. S., Looper, M. L., Callaway, T. R., Genovese, K. J., Bischoff, K. M., ... Nisbet, D. J. (2003). Antimicrobial susceptibility and factors affecting the shedding of E. coli O157:H7 and Salmonella in dairy cattle. Letters in Applied Microbiology, 37(5), 392-398. http://dx.doi.org/10.1046/j.1472-765X.2003.01417.x

Food and Agriculture Organization. (2006). Manipulations avant l'abattage, méthodes d'étourdissement et d' abattage. In FAO (Ed.), Bonnes Pratiques pour l'industrie de viandes (2nd ed., pp. 1-20). Rome: Food and Agriculture Organization, Fondation Internationale Carrefour.

Food and Agriculture Organization. (2013). Food Outlook: Biannual report on global food markets (GIEWS.). Rome Italy: Trade and Market Division - FAO. Retrieved from http://www.fao.org/Giews/english/fo/index.htm

Gashe, B. A., \& Mpuchane, S. (2000). Prevalence of Salmonellae on Beef Products at Butcheries and their Antibiotic Resistance Profiles. Journal of Food Science, 65(5), 880-883. http://dx.doi.org/10.1111/j.1365-2621.2000.tb13604.x 
Gast, R. K., Guraya, R., Guard-Bouldin, J., Holt, P. S., \& Moore, R. W. (2007). Colonization of specific regions of the reproductive tract and deposition at different locations inside eggs laid by hens infected with Salmonella enteritidis or Salmonella heidelberg. Avian Diseases, 51(1), 40-44.

Gill, C. O., Badoni, M., \& McGinnis, J. C. (1999). Assessment of the adequacy of cleaning of equipment used for breaking beef carcasses. International Journal of Food Microbiology, 46(1), 1-8. http://dx.doi.org/10.1016/S0168-1605(98)00181-0

Gill, C. O., McGinnis, J. C., \& Bryant, J. (2001). Contamination of beef chucks with Escherichia coli during carcass breaking. Journal of Food Protection, 64(11), 1824-1827. http://dx.doi.org/10.1016/S0963-9969(00)00026-0

Gopinath, S., Carden, S., \& Monack, D. (2012). Shedding light on Salmonella carriers. Trends in Microbiology, 20(7), 320-327. http://dx.doi.org/10.1016/j.tim.2012.04.004

Gould, L. H., Seys, S., Everstine, K., Norton, D., Ripley, D., Reimann, D., ... Selman, C. a. (2011). Recordkeeping practices of beef grinding activities at retail establishments. Journal of Food Protection, 74(6), 1022-1024. http://dx.doi.org/10.4315/0362-028X.JFP-10-370

Gregory, N., \& Shaw, F. (2000). Penetrating Captive Bolt Stunning and Exsanguination of Cattle in Abattoirs. Journal of Applied Animal Welfare Science, 3(3), 215-230. http://dx.doi.org/10.1207/S15327604JAWS0303

Greig, J. D., \& Ravel, A. (2009). Analysis of foodborne outbreak data reported internationally for source $\begin{array}{lllll}\text { attribution. International Journal of Food Microbiology, } & \text { 130(2), } & \text { 77-87. }\end{array}$ http://dx.doi.org/10.1016/j.ijfoodmicro.2008.12.031

Guy, R. A., Tremblay, D., Beausoleil, L., Harel, J., \& Champagne, M. J. (2014). Quantification of E. coli O157 and STEC in feces of farm animals using direct multiplex real time PCR (qPCR) and a modified most probable number assay comprised of immunomagnetic bead separation and qPCR detection. Journal of Microbiological Methods, 99(1), 44-53. http://dx.doi.org/10.1016/j.mimet.2014.02.002

Haileselassie, M., Taddele, H., Adhana, K., Kalayou, S., \& Tadesse, G. (2013). Food safety knowledge and practices of abattoir and butchery shops and the microbial profile of meat in Mekelle City, Ethiopia. Asian Pacific Journal of Tropical Biomedicine, 3(5), 407-12. http://dx.doi.org/10.1016/S2221-1691(13)60085-4

Hald, T., Wingstrand, A., Swanenburg, M., Von Altrock, A., \& Thorberg, B. M. (2003). The occurrence and epidemiology of Salmonella in European pig slaughterhouses. Epidemiol. Infect., 131, 1187-1203.

Hassanein, R., Fathi, S., Ali, H., \& El-malek, A. M. A. (2011). Detection and identification of Salmonella species in minced beef and chicken meats by using Multiplex PCR in Assiut city. Veterinary World, 4(1), 5-11.

Hauge, S. J., Nafstad, O., Røtterud, O.-J., \& Nesbakken, T. (2012). The hygienic impact of categorisation of cattle by hide cleanliness in the abattoir. Food Control, 27(1), 100-107. http://dx.doi.org/10.1016/j.foodcont.2012.03.004

Heim, D., Löpfe, J., Mumford, E., \& Speedy, A. (2007). Transmissible spongiform encephalopathies management at the slaughterhouse. In Management of transmissible spongiform encephalopathies in meat production (pp. 39-44). Rome Italy: Food and Agriculture Organization.

Heinz, G., \& Hautzinger, P. (2007). Principle of meat processing technology. In Meat Processing Technology for Small to Medium Scale Producers.

Heredia, N., García, S., Rojas, G., \& Salazar, L. (2001). Microbiological condition of ground meat retailed in Monterrey, Mexico. Journal of Food Protection, 64(8), 1249-1251.

Huffman, R. D. (2002). Current and future technologies for the decontamination of carcasses and fresh meat. Meat Science, 62(3), 285-294.

Hugas, M., \& Tsigarida, E. (2008). Pros and cons of carcass decontamination: The role of the European Food Safety Authority. Meat Science, 78(1-2), 43-52. http://dx.doi.org/10.1016/j.meatsci.2007.09.001

Jackson, V., Blair, I. S., McDowell, D. A., Kennedy, J., \& Bolton, D. J. (2007). The incidence of significant foodborne pathogens in domestic refrigerators. Food Control, 18, 346-351.

Jay, M. J., Loessner, J. M., \& Golden, A. D. (2005). Food Borne Diseases. In F. S. T. Series (Ed.), Modern Food Microbiology (7th ed., pp. 619-650). California: Springer US. http://dx.doi.org/10.1007/b100840 
Jiménez, S. M., Tiburzi, M. C., Salsi, M. S., Moguilevsky, M. a, \& Pirovani, M. E. (2009). Survival of Salmonella on refrigerated chicken carcasses and subsequent transfer to cutting board. Letters in Applied Microbiology, 48(6), 687-91. http://dx.doi.org/10.1111/j.1472-765X.2009.02596.x

Johansson, A., Berglund, L., Eriksson, U., Göransson, I., Wollin, R., Forsman, M., ... Sjöstedt, A. (2000). Comparative analysis of PCR versus culture for diagnosis of ulceroglandular tularemia. Journal of Clinical Microbiology, 38(1), 22-26.

Juneja, V. K., Eblen, B. S., \& Ransom, G. M. (2001). Thermal Inactivation of Salmonella spp . in Chicken Broth, Beef, Pork, Turkey, and Chicken: Determination of D- and Z-values. Journal of Food Science, 66(1), 146-152. http://dx.doi.org/10.1111/j.1365-2621.2001.tb15597.x

Juneja, V. K., Snyder, O. P., \& Marmer, B. S. (1997). Thermal Destruction of Escherichia coli 0157 : H7 in beef and chicken: determination of D- and z-values. International Journal of Food Microbiology, 35, 231-237.

Khaitsa, M. L., Smith, D. R., Stoner, J. a, Parkhurst, a M., Hinkley, S., Klopfenstein, T. J., \& Moxley, R. a. (2003). Incidence, duration, and prevalence of Escherichia coli O157:H7 fecal shedding by feedlot cattle during the finishing period. Journal of Food Protection, 66(11), 1972-1977.

Kiermeier, A., Bobbitt, J., Vanderlinde, P., Higgs, G., Pointon, A., \& Sumner, J. (2006). Use of routine beef carcase Escherichia coli monitoring data to investigate the relationship between hygiene status of incoming stock and processing efficacy. International Journal of Food Microbiology, 111(3), 263-269. http://dx.doi.org/10.1016/j.ijfoodmicro.2006.05.006

Koohmaraie, M., Scanga, J., De La Zerda, M., Koohmaraie, B., Tapay, L., \& Beskhlebnaya, V. (2012). Tracking the sources of salmonella in ground beef produced from nonfed cattle. Journal of Food Protection, 75(8), 1464-1468. http://dx.doi.org/10.4315/0362-028X.JFP-11-540.Tracking

Korsak, N., Clinquart, A., \& Daube, G. (2004). Salmonella spp . dans les denrées alimentaires d ' origine animale : un réel problème de santé publique? Ann. Méd. Vét, 148, 174-193.

Kothary, M. H., \& Babu, U. S. (2001). Infective dose of foodborne pathogens in volunteers: A review. Journal of Food Safety, 21, 49-73.

Loretz, M., Stephan, R., \& Zweifel, C. (2011). Antibacterial activity of decontamination treatments for cattle hides and beef carcasses. Food Control, 22, 347-359. http://dx.doi.org/10.1016/j.foodcont.2010.09.004

Mackey, B. M., \& Derrick, C. M. (1979). Contamination of the Deep Tissues of Carcasses by Bacteria Present on the Slaughter Instruments or in the Gut. Journal of Applied Bacteriology, 46(2), 355-366. http://dx.doi.org/10.1111/j.1365-2672.1979.tb00832.x

Magwira, C. a, Gashe, B. a, \& Collison, E. K. (2005). Prevalence and antibiotic resistance profiles of Escherichia coli O157:H7 in beef products from retail outlets in Gaborone, Botswana. Journal of Food Protection, 68(2), 403-6.

Mainil, J. G., \& Daube, G. (2005). Verotoxigenic Escherichia coli from animals, humans and foods: who's who? Journal of Applied Microbiology, 98(6), 1332-44. http://dx.doi.org/10.1111/j.1365-2672.2005.02653.x

McCann, M. S., Sheridan, J. J., McDowell, D. A., \& Blair, I. S. (2006). Effects of steam pasteurisation on Salmonella Typhimurium DT104 and Escherichia coli O157:H7 surface inoculated onto beef, pork and chicken. Journal of Food Engineering, 76(1), 32-40. http://dx.doi.org/10.1016/j.jfoodeng.2005.05.024

McCleery, D. R., Stirling, J. M. E., McIvor, K., \& Patterson, M. F. (2008). Effect of ante- and postmortem hide clipping on the microbiological quality and safety and ultimate $\mathrm{pH}$ value of beef carcasses in an EC-approved $\begin{array}{lllll}\text { abattoir. Journal of } & \text { Applied } & \text { Microbiology, } & 104(5), & 1471-9 .\end{array}$ http://dx.doi.org/10.1111/j.1365-2672.2007.03670.x

McEntire, J., Acheson, D., Siemens, A., Eilert, S., \& Robach, M. (2014). The Public Health Value of Reducing Salmonella Levels in Raw Meat and Poultry. Food Protection Trends, 34(6), 386-392.

McEvoy, J. M., Doherty, A. ., Sheridan, J. J., Blair, I. S., \& McDowell, D. A. (2001). Use of steam condensing at subatmospheric pressures to reduce Escherichia coli O157:H7 numbers on bovine hide. Journal of Food Protection, 64(11), 1655-1660.

McEvoy, J. M., Doherty, A. M., Finnerty, M., Sheridan, J. J., McGuire, L., Blair, I. S., ... Harrington, D. (2000). The relationship between hide cleanliness and bacterial numbers on beef carcasses at a commercial abattoir. Letters in Applied Microbiology, 30(5), 390-395. 
McEvoy, J. M., Doherty, A. M., Sheridan, J. J., Bailey, D. G., Blair, I. S., \& McDowell, D. A. (2003). The effects of treating bovine hide with steam at subatmospheric pressure on bacterial numbers and leather quality. Letters in Applied Microbiology, 37(4), 344-348. http://dx.doi.org/10.1046/j.1472-765X.2003.01406.x

McEvoy, J. M., Sheridan, J. J., Blair, I. S., \& McDowell, D. A. (2004). Microbial contamination on beef in relation to hygiene assessment based on criteria used in EU Decision 2001/471/EC. International Journal of Food Microbiology, 92(2), 217-225. http://dx.doi.org/10.1016/j.ijfoodmicro.2003.09.010

Mies, P. D., Covington, B. R., Harris, K. B., Lucia, L. M., Acuff, G. R., \& Savell, J. W. (2004). Decontamination of cattle hides prior to slaughter using washes with and without antimicrobial agents. Journal of Food Protection, 67(3), 579-582.

Millemann, Y. (2008). Les Salmonelloses et les collibacilloses septicémiques. In J. Gourreau (Ed.), Maladies des bovins (4th ed., pp. 56-67). France: Edition France Agricole.

Mohammed, M. A., Sallam, K. I., Eldaly, E. A. Z., Ahdy, A. M., \& Tamura, T. (2014). Occurrence, serotypes and virulence genes of non-O157 Shiga toxin-producing Escherichia coli in fresh beef, ground beef, and beef burger. Food Control, 37, 182-187. http://dx.doi.org/10.1016/j.foodcont.2013.09.035

Narvaez-Bravo, C., Miller, M. F., Jackson, T., Jackson, S., Rodas-Gonzalez, a, Pond, K., ... Brashears, M. M. (2013). Salmonella and Escherichia coli O157:H7 prevalence in cattle and on carcasses in a vertically integrated feedlot and harvest plant in Mexico. Journal of Food Protection, 76(5), 786-95. http://dx.doi.org/10.4315/0362-028X.JFP-12-079

Nastasijevic, I., Mitrovic, R., \& Buncic, S. (2008). Occurrence of Escherichia coli O157 on hides of slaughtered cattle. Letters in Applied Microbiology, 46(1), 126-31. http://dx.doi.org/10.1111/j.1472-765X.2007.02270.x

Nesbakken, T., Nerbrink, E., Rotterud, O. J., \& Borch, E. (1994). Reduction of Yersinia entercolitica and Listeria spp. on pig carcasses by enclosure of the rectum during slaughter. International Journal of Food Microbiology, 23(2), 197-208. http://dx.doi.org/10.1016/0168-1605(94)90052-3

Nielsen, L. R. (2013). Review of pathogenesis and diagnostic methods of immediate relevance for epidemiology and control of Salmonella Dublin in cattle. Veterinary Microbiology, 162(1), 1-9. http://dx.doi.org/10.1016/j.vetmic.2012.08.003

Niyonzima, E., Bora, D., \& Ongol, M. P. (2013). Assessment of beef meat microbial contamination during skinning, dressing , transportation and marketing at a commercial abattoir in Kigali city, Rwanda. Pakistan Journal of Food Science, 23(3), 133-138.

Nou, X., Rivera-Betancourt, M., Bosilevac, J. M., Wheeler, T. L., Shackelford, S. D., Gwartney, B. L., ... Koohmaraie, M. (2003). Effect of chemical dehairing on the prevalence of Escherichia coli O157:H7 and the levels of aerobic bacteria and Enterobacteriaceae on carcasses in a commercial beef processing plant. Journal of Food Protectionn, 66(11), 2005-2009.

Nychas, G.-J. E., Skandamis, P. N., Tassou, C. C., \& Koutsoumanis, K. P. (2008). Meat spoilage during distribution. Meat Science, 78(1-2), 77-89. http://dx.doi.org/10.1016/j.meatsci.2007.06.020

O’Brien, S. B., Duffy, G., Carney, E., Sheridan, J. J., Mcdowell, D. A., \& Blair, I. . (2005). Prevalence and numbers of Escherichia coli O157 on bovine hides at a beef slaughter plant. Journal of Food Protection, 68(4), $660-5$.

Olopoenia, L. a, \& King, a L. (2000). Widal agglutination test - 100 years later: still plagued by controversy. Postgraduate Medical Journal, 76(892), 80-84. http://dx.doi.org/10.1136/pmj.76.892.80

Phillips, D., Sumner, J., Alexander, J. F., \& Dutton, K. M. (2001). Microbiological quality of Australian beef. Journal of Food Protection, 64(5), 692-696. Retrieved from http://www.ncbi.nlm.nih.gov/pubmed/11348002

Pinto Neto, M., Beraquet, N. J., \& Cardoso, S. (2013). Effect of chilling methods and hot-boning on quality parameters of M.longissimus lumborum from Bos indicus Nelore steer. Meat Science, 93(2), 201-206. http://dx.doi.org/10.1016/j.foodcont.2005.10.018

Prendergast, D. M., Sheridan, J. J., Daly, D. J., McDowell, D. A., \& Blair, I. S. (2003). Dissemination of central nervous system tissue from the brain and spinal cord of cattle after captive bolt stunning and carcass splitting. Meat Science, 65(4), 1201-1209. http://dx.doi.org/10.1016/S0309-1740(03)00026-3

Rheault, N., \& Quessy, S. (1999). Evaluation de la contamination microbienne des plaies de saignee lors du processus d' abattage des porcs. Canadian Veterinary Journal, 40, 261-264. 
Rhoades, J. R., Duffy, G., \& Koutsoumanis, K. (2009). Prevalence and concentration of verocytotoxigenic Escherichia coli, Salmonella enterica and Listeria monocytogenes in the beef production chain: a review. Food Microbiology, 26(4), 357-76. http://dx.doi.org/10.1016/j.fm.2008.10.012

Robertsson, J. A. (1984). Humoral antibody responses to experimental and spontaneous Salmonella infections in cattle measured by ELISA. Journal of Veterinary Medicine Serie B, 31, 367-380. http://dx.doi.org/10.1111/j.1439-0450.1984.tb01314.x

Roels, T. H., Frazak, P. a, Kazmierczak, J. J., Mackenzie, W. R., Proctor, M. E., Kurzynski, T. a, \& Davis, J. P. (1997). Incomplete sanitation of a meat grinder and ingestion of raw ground beef: contributing factors to a large outbreak of Salmonella typhimurium infection. Epidemiology and Infection, 119(2), 127-134. http://dx.doi.org/10.1017/S0950268897007851

Røtterud, O. J., Helps, C. R., Hillman, T. J., Fisher, A. V, Harbour, D., Anil, H., \& Nesbakken, T. (2006). Hot boning of intact carcasses: a procedure to avoid central nervous system self-contamination in beef and beef products. Journal of Food Protection, 69(2), 405-411.

Russell, N. J. (2002). Bacterial membranes: The effects of chill storage and food processing. An overview. $\begin{array}{lllll}\text { International Journal of Food } & \text { Microbiology, } & \text { 79(1-2), } & \text { 27-34. }\end{array}$ http://dx.doi.org/10.1016/S0168-1605(02)00176-9

Russell, N. J., Evans, R. I., ter Steeg, P. F., Hellemons, J., Verheul, a, \& Abee, T. (1995). Membranes as a target for stress adaptation. International Journal of Food Microbiology, 28(2), 255-261. http://dx.doi.org/10.1016/0168-1605(95)00061-5

Savell, J. W., Mueller, S. L., \& Baird, B. E. (2005). The chilling of carcasses. Meat Science, 70, 449-459. http://dx.doi.org/10.1016/j.meatsci.2004.06.027

Scallan, E., Hoekstra, R. M., Angulo, F. J., Tauxe, R. V., Widdowson, M.-A., Roy, S. L., ... Griffin, P. M. (2011). Foodborne Illness Acquired in the United States-Major Pathogens. Emerging Infectious Diseases, 17(1), 7-15. http://dx.doi.org/10.3201/eid1701.P11101

Scanga, J. A., Grona, A. D., Belk, K. E., Sofos, J. N., Bellinger, G. R., \& Smith, G. C. (2000). Microbiological contamination of raw beef trimmings and ground beef. Meat Science, 56(2), 145-52.

Sheridan, J. J. (1998). Sources of contamination during slaughter and measures for control. Journal of Food Safety, $18,321-339$.

Sheridan, J. J., Lynch, B., \& Harrington, D. (1992). The effect of boning and plant cleaning on the contamination of beef cuts in a commercial boning hall. Meat Science. http://dx.doi.org/10.1016/0309-1740(92)90105-D

Sierra, M. L., Sheridan, J. J., \& McGuire, L. (1997). Microbial quality of lamb carcasses during processing and the acridine orange direct count technique (a modified DEFT) for rapid enumeration of total viable counts. $\begin{array}{lllll}\text { International Journal of Food } & \text { Microbiology, }\end{array}$ http://dx.doi.org/10.1016/S0168-1605(96)01247-0

Small, A., \& Buncic, S. (2009). Potential for the cross-contamination of the hides of cattle while they are held in lairage. The Veterinary Record, 164(9), 260-265. http://dx.doi.org/10.1136/vr.164.9.260

Small, A., Reid, C. A., Avery, S. M., Karabasil, N., Crowley, C., \& Buncic, S. (2002). Potential for the spread of Escherichia coli O157, Salmonella, and Campylobacter in the lairage environment at abattoirs. Journal of Food Protection, 65(6), 931-6.

Small, A., Wells-Burr, B., \& Buncic, S. (2005). An evaluation of selected methods for the decontamination of cattle hides prior to skinning. Meat Science, 69(2), 263-268. http://dx.doi.org/10.1016/j.meatsci.2004.07.005

Stevens, A., Kaboré, Y., Perrier-Gros-Claude, J.-D., Millemann, Y., Brisabois, A., Catteau, M., ... Dufour, B. (2006). Prevalence and antibiotic-resistance of Salmonella isolated from beef sampled from the slaughterhouse and from retailers in Dakar (Senegal). International Journal of Food Microbiology, 110(2), 178-186. http://dx.doi.org/10.1016/j.ijfoodmicro.2006.04.018

Swanson, J. C., \& Morrow-Tesch, J. (2001). Cattle transport: Historical, research, and future perspectives. Journal of Animal Science, 79, 102-109.

Tafida, S. Y., Kabir, J., Kwaga, J. K. P., Bello, M., Umoh, V. J., Yakubu, S. E., .. Hendriksen, R. (2013a). Occurrence of Salmonella in retail beef and related meat products in Zaria, Nigeria. Food Control, 32(1), 119-124. http://dx.doi.org/10.1016/j.foodcont.2012.11.005 
Tafida, S. Y., Kabir, J., Kwaga, J. K. P., Bello, M., Umoh, V. J., Yakubu, S. E., ... Hendriksen, R. (2013b). Occurrence of Salmonella in retail beef and related meat products in Zaria, Nigeria. Food Control, 32 , 119-124. http://dx.doi.org/10.1016/j.foodcont.2012.11.005

Temellí, S., Eyİgör, A., \& Anar, Ş. (2012). Prevalence of Escherichia coli O157 in red meat and meat products determined by VIDAS ECPT and LightCycler PCR. Turk. J. Vet. Anim. Sci, 36(3), 305-310. http://dx.doi.org/10.3906/vet-1107-38

Teunis, P. F. M., Kasuga, F., Fazil, A., Ogden, I. D., Rotariu, O., \& Strachan, N. J. C. (2010). Dose-response modeling of Salmonella using outbreak data. International Journal of Food Microbiology, 144(2), $243-249$. http://dx.doi.org/10.1016/j.ijfoodmicro.2010.09.026

Vipham, J., Brashears, M., Loneragan, G., Echeverry, A., Brooks, J., Chaney, W., \& Miller, M. (2012). Salmonella and Campylobacter baseline in retail ground beef and whole-muscle cuts purchased during 2010 in the United $\begin{array}{lllll}\text { States. Journal of } & \text { Food } & \text { 2110-2115. }\end{array}$ http://dx.doi.org/10.4315/0362-028X.JFP-12-077.Salmonella

Warriner, K., Tg, A., Kaur, S., \& Ce, D. (2002). Cross-contamination of carcasses and equipment during pork processing. Journal of Applied Microbiology, 93(1), 169-77.

Wheatley, P., Giotis, E. S., \& Mckevitt, A. I. (2014). Effects of slaughtering operations on carcass contamination in an Irish pork production plant. Irish Veterinary Journal, 67(1), 1-6. http://dx.doi.org/10.1186/2046-0481-67-1

Wong, L. F., Hald, T., Wolf, P. J. Van Der, \& Swanenburg, M. (2002). Epidemiology and control measures for Salmonella in pigs and pork. Livestock Production Science, 76, 215-222.

Wotton, S. B., Gregory, N. G., Whittington, P. E., \& Parkman, I. D. (2000). Electrical stunning of cattle. The Veterinary Record, 147(24), 681-684.

Yang, X., Balamurugan, S., \& Gill, C. O. (2011). Effects on the development of blown pack spoilage of the initial numbers of Clostridium estertheticum spores and Leuconostoc mesenteroides on vacuum packed beef. Meat Science, 88(3), 361-367. http://dx.doi.org/10.1016/j.meatsci.2011.01.010

\section{Copyrights}

Copyright for this article is retained by the author(s), with first publication rights granted to the journal.

This is an open-access article distributed under the terms and conditions of the Creative Commons Attribution license (http://creativecommons.org/licenses/by/3.0/). 